\title{
GLOBALIZATION, INTERNATIONAL HUMAN RightS, AND CIVIL PROCEDURE
}

\author{
TREVOR C.W. FARROW*
}

This article discusses the modern convergence of three traditionally separate topics: globalization and international human rights on the one hand, and civil procedure on the other. Its project is twofold: first, to highlight the role of domestic legal processes and communities in the advancement of the post-World War II international human rights project. Secondin contemplation of the specific context of teaching civil procedure - to help bring alive the power and increasingly-global context of civil procedure for the benefit of students.
Cet article porte sur la convergence moderne de trois sujets traditionnellement séparés : la mondialisation et les droits internationaux de la personne d'une part et les procédures civiles d'autre part. Le projet a deux volets : premièrement, faire ressortir le rôle des processus juridiques nationaux et des collectivités dans l'avancement des droits internationaux de la personne d'après La Deuxième guerre mondiale et deuxièmement, compte tenu du contexte particulier d'enseigner les procédures civiles, donner vie au pouvoir et au contexte de plus en plus mondial de la procédure civile pour les étudiants.

\section{TABLE OF CONTENTS}

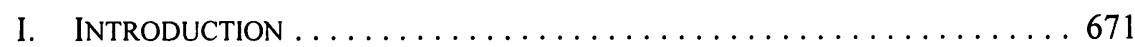

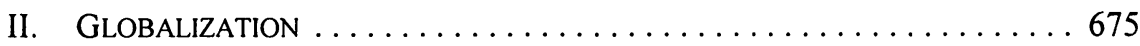

III. INTERNATIONAL HUMAN RIGHTS . . . . . . . . . . . . . . . . . 677

A. THE "INTERNATIONAL BILl of Rights" . . . . . . . . . . . . 678

B. CORPORATE CODES OF CONDUCT .............. 681

C. APPLICATION TO INDIVIDUALS AND CORPORATIONS ........ 683

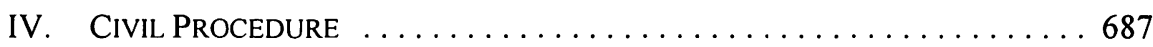

A. Globalization and Domestic Civil Courts . . . . . . . . . . . 687

B. JURISDICTION . . . . . . . . . . . . . . . . . . . . . . 690

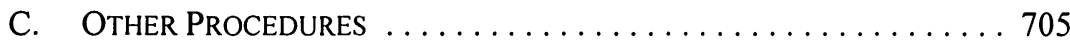

V. CONCLUSION .......................... 711

\section{INTRODUCTION}

[T]he business of litigation, like commerce itself, has become increasingly international.

The train trip from Delhi to Kanniyakumari - a small town at the southern tip of India - takes about three days. I recently made this trip. One of the stops along the way was at the city of Bhopal in the state of Madhya Pradesh. When looking at the faces of people going about their business at the Bhopal train station and surrounding areas, it was difficult to

University of Alberta, Faculty of Law. This article is based on a presentation given at the Canadian Law and Society Association annual conference in Halifax, N.S. on 3 June 2003. The author is grateful to the University of Alberta for research funding, Annalise Acorn, Jane Bailey, C. Raj Kumar, two anonymous reviewers for comments, and Ian Smith for comments and excellent research assistance. Amchem Products Inc. v. British Columbia (Workers' (Compensation Board), [1993] I S.C.R. 897 at 911, 150 N.R. 321 at 333, Sopinka J. [Amchem cited to N.R.]. 
fathom that approximately 8,000 people - mostly "impoverished squatters"2 — died and that approximately 600,000 people were injured less than 20 years ago in that city as a result of a massive industrial gas leak. ${ }^{3}$ The event has been described similarly as "the most tragic industrial disaster in history"4 and "perhaps history's worst industrial catastrophe."

So what does the Bhopal disaster - one of several case examples looked at in this article - have to do with globalization, international human rights, and civil procedure? The connection to globalization is clear. The December 1984 gas leak came from a chemical plant owned by Union Carbide India Limited (UCIL). The majority shareholder of UCIL was Union Carbide Corporation (UCC), a corporation incorporated thousands of miles away in the state of New York. ${ }^{6}$ UCC, through UCIL, was ${ }^{7}$ but one example of many multi-national corporations (MNCs) doing business, directly or indirectly, in multiple jurisdictions around the world.

The connection to international human rights is equally clear. Ongoing processes of globalization - most obviously but not exclusively commercial globalization - have had concomitant impacts on the rights of individuals enumerated in various international human rights regimes. The Bhopal tragedy is but one example of how basic international human rights - including meaningful access to justice, the protection of the home, safe and healthy working conditions, adequate standards of living and physical and mental health, labour rights, and the like - are potentially involved and often dramatically affected by the operations of MNCs. As one commentator has argued, "[I]ong before the antiglobalization movement gained prominence, and before chief executives in handcuffs became a news staple, Union Carbide became, for many, an emblem of the evils of multinationalism." Allegations of "poor safety procedures and maintenance" on the part of UCIL have been cited as the cause of the gas leak and the resulting devastation to its victims. ${ }^{9}$ Further, to add

In re Union Carbide Corp. Gas Plant Disaster at Bhopal, India, 634 F.Supp. 842 at 844 (S.D.N.Y. 1986), Keenan Dist. J., mod'd \& aff'd 809 F.2d 195 (2d Cir. 1987), cert. den'd 484 U.S. 871 (1987) [Union Carbide cited to F.Supp. unless otherwise indicated]. See also subsequent related cases including In re Union Carbide Corp. Gas Plant Disaster, [1992] U.S. Dist. LEXIS 1909 (S.D.N.Y. 1992) (Lexis), aff'd Bi v. Union Carbide Chems. and Plastics Co., 984 F.2d 582 (2d Cir. 1993), cert. den'd.510.U.S. 862 (1993). See also Bano v. Union Carbide Corp., [2000] U.S. Dist. LEXIS 12326 (S.D.N.Y. 2000) (Lexis), aff'd, vac'd in part \& remanded 273 F.3d 120 (2d Cir. 2001) [Bano], claim dis'd and motion grant'd [2003] U.S. Dist. LEXIS 4097 (S.D.N.Y. 2003) (Lexis) [Bano Motion]. Final death estimates relating to the Bhopal disaster range from approximately 2,000 to 20,000 people The injury estimates range from approximately 200,000 to almost 600,000 people. See e.g. Union Carbide, ibid. at 844; Errol Mendes \& Ozay Mehmet, Global Governance, Economy and Law: Waiting for Justice (London: Routledge, 2003) at 121; Amy Waldman "Bhopal Seethes, Pained and Poor 18 Years Later" The New York Times (21 September 2002) A3.

Union Carbide, supra note 2 at 844.

Bano, supra note 2 at 122.

Union Carbide, supra note 2 at 844.

On 9 September 1994 UCC sold all of its shares in UCIL to McLeod Russell (India) Limited (Bano Motion, supra note 2). UCC itself is now a "wholly owned subsidiary" of the Dow Chemical Company. The Dow Chemical Company, News Center, Manufacturing Site News, "Union Carbide Shuts Down Texas City Olefins Plant as Planned" (13 June 2003), online: The Dow Chemical Company $<$ www.dow.com/dow_news/manufacturing/2003/20030613a.htm>.

Waldman, supra note 3 .

Ibid. 
insult to injury, one recent report indicates that "the site, which still has not been cleaned up, may be leaking contaminants into local groundwater."

So what about civil procedure? On one hand, the civil procedure rules and texts that cover my desk in Canada could not have seemed farther away at the time of my visit to Bhopal. On the other hand, however, they could not have felt closer. After all, it was a civil procedure process - interpreted and applied thousands of miles away in the State of New York - that had perhaps the biggest single impact on how the Bhopal disaster has been handled legally over the past 20 years.

After the devastation, victims and their families sought significant compensation through litigation in a federal court in the Southern District of New York. Before the merits of the case were reached, the case was "dismissed" in the U.S. on a procedural motion, "on the grounds of forum non conveniens," 12 in "deference to the Indian government's efforts ... to pursue a global resolution in India." 13 After years of ongoing litigation in India and again (unsuccessfully) in the U.S., a settlement of approximately one eighth of the initial claim was reached on behalf of the victims. ${ }^{14}$ Notwithstanding the settlement, to a large extent these victims have felt this amount to be seriously "inadequate." 15

Civil procedure is, in the end, about power. It is about power - albeit often retrospectively - to regulate individual and corporate behaviour. It is about power to manage efficiently and resolve expectations, transactions, and disputes. And, ultimately, it is about power to access meaningful substantive rights and remedies in a fair and fulsome way. ${ }^{16}$ In the context of globalization and international human rights, far from merely being a tool of parochial domestic process, civil procedure has become a gatekeeper in this era of modern commerce and social intercourse: a gatekeeper to the access of meaningful justice - through the protection and/or the recognition of basic rights and liberties - for parties involved in civil matters with global contacts.

In addition to my visit through Bhopal, it has been my experience as a professor of both civil procedure and international law that has prompted my interest in this cross-doctrinal research, and more specifically, the important but seldom-discussed links between globalization and international human rights on the one hand and civil procedure on the other. ${ }^{17}$ Teaching civil procedure is a notoriously difficult task. As Mr. Justice Côté of the Alberta Court of Appeal, one of the leading Canadian thinkers in the area of civil procedure

Ibid. For a further discussion of the environmental contamination of the Bhopal disaster, see Bano Motion, supra note 2 at 3-8.

Union Carbide, supra note 2 at 867.

Ibid.

Bano, supra note 2 at 122.

Ibid. at 123.

J. Talpis \& S.L. Kath, "The Exceptional as Commonplace in Quebec Forum Non Conveniens Law: Cambior, a Case in Point" (2000), 34 R.J.T. 761 at para. 146. See also Waldman, supra note 3.

16 My thinking on this issue of power has been influenced by Stephen B. Burbank, "Procedure, Politics. and Power" (2002) 52 J. Legal Educ. 342.

17 I am grateful to Jeffrey Hackney who helped stimulate my thinking about the connections between human rights and civil procedure. 
theory and practice, ${ }^{18}$ commented to me, teaching civil procedure is like "teaching the geography of a planet to which students have never been." ${ }^{\prime \prime}$

In my view, one of the main reasons for this perennial difficulty has been the traditional, rule-based, and often parochial approach to the subject. We have failed to recognize adequately that local rules of civil procedure have become increasingly engaged with social, political, economic, and legal matters beyond our borders, specifically including issues of globalization and international human rights. As Paul Schiff Berman has recently commented, there is a "convergence ... in an era of globalization" of doctrinal areas such as "international law ... and ... civil procedure." 20 To the extent that we agree with the proposition that "globalization is changing the world,"21 we need to recognize that civil procedure, too, must adapt to and participate in this changing climate.

The purpose of this article - admittedly experimental, aspirational, and pedagogical is to discuss and highlight this important convergence. Its project is twofold. First, in this era of globalization the legal community needs to be sensitive to, and available for the protection of, basic human rights and needs. Essentially, domestic lawyers and domestic courts need to be available for the advancement of the post-World War II international human rights project. ${ }^{22}$ This protection and advancement will come from existing legal and political tools, specifically including domestic rules of civil procedure. Here we see the converging trajectories of globalization and international human rights on the one hand and civil procedure on the other. Providing this protection is particularly crucial when foreign jurisdictions are unable or unwilling to do so adequately. ${ }^{23}$ I say this article is experimental and aspirational because these international and domestic tools and topics have not traditionally been brought together in legal discourse, and further, because the connections between them - particularly between international human rights regimes and domestic rules of civil procedure - are still being developed. I see those with interests in both international human rights and civil procedure - students, academics, practitioners, legislators and the judiciary - as my primary interlocutors in this first aspect of the project.

See e.g. W.A. Stevenson \& J.E. Côté, Civil Procedure Encyclopedia (Edmonton: Juriliber, 2003). The Honourable J.E. Côté, Justice of Appeal (Meeting, Alberta Court of Appeal, 11 December 2001). Paul Schiff Berman, "The Globalization of Jurisdiction" (2002) 151 U. Pa. L. Rev. 311 at 544.

This phrase is taken from part of the title of Tyler Cowen's recent book: T. Cowen, Creative Destruction: How Globalization is Changing the World's Cultures (Princeton: Princeton University Press, 2002).

Beth Stephens has described ongoing international efforts to enforce human rights as the "global campaign to enforce international human rights norms" (Beth Stephens, "Translating Filártiga: A Comparative and International Law Analysis of Domestic Remedies For International Human Rights Violations" (2002) 27 Yale J. Int'l L. 1 at 35 ["Translating Filártiga"]).

For example, in Union Carbide, supra note 2 at 847, the Government of India argued at first instance that "to a great extent" the "Indian courts do not offer an adequate forum for this litigation by virtue of the relative 'procedural and discovery deficiencies [which] would thwart the victims' quest for' justice." See also infra notes 159-65 and accompanying text. On appeal, however, the Indian Government "changed its position" and "now supports the district court's order" dismissing the claim on grounds of forum non conveniens (Union Carbide, 809 F.2d 195 at 201 (2d Cir. 1987)). Similarly, in Jota v. Texaco, Inc., 57 F.3d 153 (2d Cir. 1998) - an environmental damage case - the government of Ecuador took the position that the claims at issue should be tried in the U.S. (cited in Beth Stephens, "The Amorality of Profit: Transnational Corporations and Human Rights" (2002) 20 Berkeley J. Int"I L. 45 at ff. VI.A. note 222 and surrounding text ["The Amorality of Profit"]). 
Second, to help facilitate the first aspect of the project, the article makes these important connections - in contemplation of the specific context of teaching civil procedure - in order to help bring alive the power and increasingly-global context of civil procedure for the benefit of civil procedure students. It is this second aspect of the project that makes it pedagogical in nature.

The article is structurally divided into three main parts that correspond to the three topics set out in the title. The exercise of linking these topics largely culminates in Part IV. There, I look at four relevant "civil procedure tools": primarily jurisdictional tools, as applied in Union Carbide and other cases, class actions, the recognition of foreign judgments, and discovery in extraterritorial jurisdictions. This discussion of civil procedure tools and cases is used to link those tools and cases to the topics of globalization and international human rights developed in Parts II and III.

\section{Globalization}

So what am I talking about when I refer to "globalization" in this article? Globalization is a notoriously thorny and elusive concept. According to one commentator, "[g]lobalization exists today as perhaps the most widely cited (yet least understood) concept in academic discourse." 24 Elsewhere I have argued that the term "globalization" evades simple definition..$^{25}$ More than simply an historically-contingent event, globalization is a nuanced and expansive process involving a wide range of geographically-relevant political, economic, social and cultural connections and changes that are being created by and visited upon our personal and community affairs. It therefore involves - in this broad sense - much more than what is often seen largely as a process of increased and interconnected trade, technology, and the movement of capital. ${ }^{26}$

For purposes of this project, however, I am primarily interested in only part of this broad concept of globalization: private commerce. A defining characteristic of this narrow aspect of globalization has been the internationalization of commercial affairs, largely through the presence of $\mathrm{MNCs}$ - as evidenced by the name itself — in various jurisdictions around the

Jason F. Hellwig, "The Retreat of the State? The Massachusetts Burma Law and Local Empowerment in the Context of Globalization(s)" (2000) 18 Wis. Int'l L.J. 477 at 485.

25 See e.g. Trevor C.W. Farrow, "Reviewing Globalization: Three Competing Stories, Two Emerging Themes, and How Law Schools Can and Must Participate" (2003) 13 Meikei L. Rev. 176 at 191-92, trans. into Japanese by M. Kuwahara, (2003) 44 Aichigakuin L. Rev. 29.

26. For useful general sources on the topic of globalization theory, see e.g. David Held et al., Global Transformations: Politics, Economics and Culture (Stanford: Stanford University Press, 1999); William Twinning, Globalisation and Legal Theory (London: Butterworths, 2000); Paul Hirst \& Grahame Thompson, Globalization in Question: The International Economy and the Possibilities of Governance, 2d ed. (Cambridge: Polity Press, 1999). See also Dani Rodrik, Has Globalization Gone Too Far? (Washington, D.C.: Institute of International Economics, 1997); A.S. Bhalla, ed., Globalization, Growth and Marginalization (Ottawa: International Development Research Centre, 1998); and Barry B. Hughes, International Futures: Choices in the Creation of a New World Order, 2d ed. (Boulder, CO: Westview Press, 1996). 
world. ${ }^{27}$ According to Stephens, MNCs "are the driving force behind the global economy." 28 Further, as another commentator recently acknowledged:

[o]ne feature of economic globalization has been the great diversification of corporate holdings, both in terms of commodity portfolios and geographical spheres of operation, and a company's plant, equipment, and other assets will frequently be located in a strategic range of countries. Such diversification characterizes the corporate behaviour of vast multinational corporations.... This collective burgeoning of transnational activity is seen most clearly in ... international commerce. ${ }^{29}$

In a nutshell, when talking about globalization in this article, I am largely contemplating the global activities of MNCs. For further clarification, this narrow sense of globalization does not focus on issues of public international trade policy. Public international trade, and its impact on human rights, has been the topic of vocal discussion for some time now, most publicly at anti-globalization protests ${ }^{30}$ at and since the 1999 World Trade Organization protests in Seattle. ${ }^{31}$ For purposes of this project, therefore, I am more interested in private commercial activity - which, while perhaps facilitated by public international trade regimes, ${ }^{32}$ has traditionally been regulated, if at all, largely by domestic legislation, rules of civil procedure, and private international law. My focus, therefore, is private commercial activity and its important connections with international human rights and civil procedure.

For a recent discussion of this aspect of globalization, see e.g. Joseph E. Stiglitz, Globalization and its Discontents (New York: W.W. Norton \& Company, 2003) at 8-10. See also generally Thomas L. Friedman, The Lexus and the Olive Tree: Understanding Globalization (New York: Anchor Books, 2000).

Stephens, "The Amorality of Profit," supra note 23 at ff. VII. As reported by Robert McCorquodale, "[g]lobalisation has led to the situation where more than 50 per cent of the world's 100 largest economies are corporations" ("Human Rights and Global Business" in Stephen Bottomley \& David Kinley, eds., Commercial Law and Human Rights (Aldershot: Ashgate Publishing Limited, 2002) at 90 [citation omitted]).

Andrew Bell, Forum Shopping and Venue in Transnational Litigation (Oxford: Oxford University Press, 2003) at 3, 5 [Bell, Forum Shopping].

For recent discussions of anti-globalization protests and their treatment by police, see Trevor C.W. Farrow, "Negotiation, Mediation, Globalization Protests and Police: Right Processes; Wrong System, Issues, Parties and Time" (2003) 28 Queen's L.J. 665; and "Citizen Participation and Peaceful Protest: Let's Not Forget APEC" in Canadian Institute for the Administration of Justice, ed., Participatory Justice in a Global Economy: The New Rule of Law? (Montréal: Éditions Thémis) [forthcoming in 2004] [Participatory Justice].

The Lawyers Committee for Human Rights has argued that, "[a]s is evident from the public protests at the meeting of the World Trade Organization in Seattle in November 1999, opposition to globalization is rising. This is based at least in part on concerns that an expanding global economy is not adequately addressing human rights, labor rights, and environmental needs." (Lawyers Committee for Human Rights, Business and Human Rights (2000) [Business and Human Rights] in Henry J. Steiner \& Philip Alston, International Human Rights in Context: Law', Politics, Morals, 2d ed. (Oxford: Oxford University Press, 2000) at 1354). For a useful treatment of this public discussion of globalization, see Maude Barlow \& Tony Clarke, Global Showdown: How the New Activists Are Fighting Global Corporate Rule (Toronto: Stoddart Publishing, 2002). For a general treatment of a number of the underlying issues in this discussion, see e.g. Jerry Mander \& Edward Goldsmith, eds., The Case Against the Global Economy, and For a Turn Toward the Local (San Francisco: Sierra Club Books, 1996). the Government of the United States, 17 December 1992, Can. T.S. 1994 no.2, 32 I.L.M. 289 (entered into force 1 January 1994). 
Several characteristics of this narrow view of globalization are worth highlighting here. First, in terms of its intersection with issues of international human rights, commercial globalization has traditionally been indifferent to the protection and fostering of human rights and, more generally, to the interests of the oppressed. Bhopal is but one example of how commercial globalization often has a significant negative impact on the basic rights of individuals. In addition, the more far-reaching this aspect of modern globalization becomes, the more it will be felt in personal and community affairs around the world. As Robert McCorquodale has recently commented:

[t]he apparent lack of concern of corporations or the business community for the plight of the oppressed has been a recurring theme of social commentators throughout the centuries.... At the beginning of the twenty-first century, the internationalization of corporations - and the creation of "global business" — has pushed this theme onto a wider canvas. This has occurred mainly due to the processes of economic globalisation. ${ }^{33}$

Second, given its de-centralized and largely private nature, international commercial activity is a notoriously difficult aspect of globalization for states to regulate publicly. As Beth Stephens has noted, the "modern multinational corporation ... model has proven difficult to regulate with the legal tools available to the governments of sovereign states." ${ }^{34}$ Put simply, the activities of MNCs have been typically able to fly under the radar of much domestic and international regulation. For example, as evidenced by the massive $1997 \mathrm{crash}$ of the Asian markets, governments have found themselves unable to control predictably the reach, depth and speed of global economic and commercial activity. ${ }^{35}$ According to Professor John Jackson:

$[t]$ [he pace of international economic activity and the developing interdependence of national economies is head spinning. Governments increasingly find it difficult to implement worthy policies concerning economic activity because such activity often crosses borders in ways that escape the reach of much of national government control. ${ }^{36}$

It is in the regulation of commercial globalization - and more specifically, its impact on international human rights - where civil procedure enters the scene. This discussion will be developed further in Part IV. First, in Part III, I discuss what I mean by the term "international human rights."

\section{INTERNATIONAL HUMAN RightS}

Traditionally, human rights have been thought of as matters of domestic jurisdiction. ${ }^{37}$ Prior to World War II, international law was largely silent on the regulation and enforcement

Supra note 28 at 89 [citation omitted]. See generally David Kinley, "Human Rights, Globalization and the Rule of Law: Friends, Foes or Family?" (2002-03) 7 U.C.L.A. J. Int'l L. \& Foreign Aff. 239.

"The Amorality of Profit," supra note 23 at ff. III.A, notes 56-78 and accompanying text.

For useful discussions of the Asian crash in the context of globalization, see e.g. Stiglitz, supra note 27 at 89-132; and Friedman, supra note 27 at $x i-x v$.

John H. Jackson, The World Trading System: Law and Policy of International Economic Relations, 2d ed. (Cambridge, MA: MIT Press, 1997) at 1.

See e.g. Malcolm N. Shaw, International Law, 4th ed. (Cambridge: Cambridge University Press, 1997, reprinted 2001) at 200 . 
of individual rights. ${ }^{38}$ As Robertson and Merrills have pointed out, " $[t]$ he protection of human rights through international action is a revolutionary idea and traditional international law had no place for it at all." ${ }^{39}$ This is primarily because international law has been thought of as available for ordering the affairs of states, not individuals. ${ }^{40}$ Even after 1945 and the birth of the Charter of the United Nations, ${ }^{41}$ rights were largely thought of as public tools enforceable, if at all, by and against states.

However, over the past fifty years, a remarkable amount of work has been done by the international community to develop binding and non-binding tools $\mathrm{s}^{42}$ that provide for increasingly meaningful protections of basic international human rights. ${ }^{43}$ As will also be discussed, ${ }^{44}$ this protection is starting to contemplate, in the context of commercial globalization, activities involving individuals, corporations and formerly private matters in domestic tribunals.

\section{A. THE "INTERNATIONAL BILL OF RIGHTS"}

\section{BACKGROUND}

So what is specifically contemplated by the term "international human rights" in this article $?^{45}$ Discussions of human rights in the international context - and violations thereof - often bring to mind specific criminal activity, war crimes, or crimes against humanity. ${ }^{46}$ Torture, involuntary servitude, execution, and genocide are typical examples. The enforcement of these rights internationally has been improved significantly over the past ten

See Hilary Charlesworth \& Christine Chinkin, The Boundaries of International Law: A Feminist Analysis (Manchester: Manchester University Press, 2000) at 201-208. See also generally Steiner \& Alston, supra note 31 at 56-135. International Protection of Human Rights, 4th ed. (Manchester: Manchester University Press, 1996) at 1 .

See e.g. Shaw, supra note 37 at 1-2; and Charlesworth \& Chinkin, supra note 38 at 23-25.

26 June 1945, Can. T.S. 1945 No. 7 [U.N. Charter].

See infra Parts III.A-B.

See e.g. Charlesworth \& Chinkin, supra note 38 at 201-208; and Hugh M. Kindred et al., International Law: Chiefly as Interpreted and Applied in Canada, 6th ed. (Toronto: Emond Montgomery, 2000) at 769-72.

45 For purposes of further clarity, this article does not purport to address head on the topic of U.S. civil human rights litigation. This tradition is discussed briefly in the context of the broader arguments being advanced in this article (see infra note 139). However, given the meaningful differences in the U.S. legislative and constitutional frameworks in this area, I do not purport to provide a comprehensive review and analysis of that jurisprudence and tradition. For useful discussions of that jurisprudence, see e.g. Stephens, Translating Filártiga," supra note 22 at 1; Stephens, "The Amorality of Profit," supra note 23 at ff. VI.B; Kathryn L. Boyd, "Collective Rights Adjudication in U.S. Courts: Enforcing Human Rights at the Corporate Level" (1999) B.Y.U.L. Rev. 1139; and H.H. Koh, "Transnational Public Law Litigation" (1991) 100 Yale L.J. 2347.

th For general discussions of these issues, see e.g. Antonio Cassese, International Criminal Law (Oxford: Oxford University Press, 2003); and Kriangsak Kittichaisaree. International Criminal Law (Oxford: Oxford University Press, 2001). 
years with the important work of non-governmental organizations (NGOs) ${ }^{47}$ and the creation of ad hoc war crimes tribunals ${ }^{48}$ and the ICC. ${ }^{49}$

However, as evidenced by the basic United Nations human rights regimes, ${ }^{50}$ the concept of "international human rights" includes a much broader spectrum of rights and remedies beyond the criminal and war crimes contexts. It is this broader spectrum of international human rights that is most relevant to the discussion in this article.

The foundational document that provides the basis for this broad spectrum of rights is the Universal Declaration of Human Rights $(U D H R) .{ }^{51}$ As stated in its preamble, the "peoples of the United Nations have ... determined to promote social progress and better standards of life in larger freedom." ${ }^{.52}$ The $U D H R$ essentially enumerates the aspirational rights, discussed further herein, ${ }^{53}$ that are generally contemplated in the preamble of the U.N. Charter.

The aspirational rights and principles set out in the $U D H R$ have been given more meaningful content by the international community through the International Covenant on

47 I have discussed elsewhere the significant international efforts of NGOs. See e.g. Farrow, supra note 25 at 193-95. One important example includes the work done by the Women's Caucus for Gender Justice (WCGJ) (see ibid. at 190-91, 194-95). The WCGJ was established by a number of women human rights activists prior to the preparatory meetings for the establishment of the International Criminal Court (ICC) (see infra note 49). The stated goals of the WCGJ included: (i) "[t]o ensure a worldwide participation of women's human rights advocates in the negotiations of the ICC treaty to lobby for an effective and independent court"; (ii) "...to educate government[] delegations and mainstream Human Rights NGOs on their commitments to women and the need to integrate a gender perspective into the U.N."; and (iii) to educate "... on women's human rights and raise public awareness of the horrific nature of crimes committed against women."(WCGJ, "About the Caucus," online: WCGJ $<$ www.iccwomen.addr.com/caucus/about.htm>). In connection with the ICC conference, the WCGJ played a significant role in shaping the vision, mandate and ultimate successful establishment of the ICC. A key element to the WCGJ's creation and ultimate success was its founding members' vision that, if left to the mainstream human rights NGOs, women's concerns would not be "appropriately defended and promoted" (ibid.). As Mary Robinson, then U.N. High Commissioner for Human Rights stated on the occasion of International Women's Day, 8 March 2000: "[a]t this juncture I would like to pay tribute to the women of the Women's Caucus for Gender Justice who have taken the experiences of women in war, identified strategies for dealing with violations and, overcoming intense opposition from many representatives at the International Criminal Court negotiations, managed to ensure that rape, sexual slavery, forced pregnancy and other forms of gender-based and sexual violence are included in the statute of the ICC" (M. Robinson, cited by WCGJ, ibid.). My understanding of the WCGJ's involvement in the Rome ICC conference benefited from a discussion with Linda $\mathrm{C}$. Reif and a panel presentation by, and follow-up discussion with Ruth B. Philips (R.B. Philips, "Domesticating Military Sexual Assault: Reimagining Women, WarCrimes, and Family Violence" (International Criminal Law: From Bosnia to the ICC, Panel Presentation, Law \& Society Association and Canadian Law \& Society Association, Joint Meetings, Vancouver, 1 June 2002)). See e.g. the International Tribunal for Former Yugoslavia, UN Doc. S/Res/827 (1993), the International Tribunal for Rwanda, UN Doc. S/Res/955 (1994).

1998 Rome Statute of the International Criminal Court, UN Doc. A/CONF. 183/9 (1998). For a discussion of such international human rights abuses in the general context of U.S. civil human rights litigation, see e.g. Stephens, "Translating Filártiga," supra note 22 at 47. See also John Doe I, et al. v. UNOCAL Corp., et al., 27 F.Supp. $2 \mathrm{~d} 1174$ (C.D.Cal. 1998). 
Civil and Political Rights $(I C C P R)^{54}$ and the International Covenant on Economic, Social and Cultural Rights (ICESCR) ${ }^{55}$ among other tools. These documents, together with the $U D H R$, are often referred to as the "international bill of rights."

\section{SPECIFIC RIGHTS}

A number of specific rights included in the international bill of rights are relevant for the purposes of this project. The first - and perhaps the most significant - is the right to an effective legal remedy. ${ }^{57}$ As a starting point, the UDHR provides that: "Everyone has the right to an effective remedy by the competent national tribunal for acts violating the fundamental rights granted him [or her] by the constitution or by law." ${ }^{58}$ As Beth Stephens has summarized, the ICCPR provides that the $U D H R$ 's "effective remedy" provided for in article 8 requires states "to develop the possibilities of judicial remedy" and "to ensure that the competent authorities shall enforce such remedies when granted." ${ }^{.59}$ Further, article 14 of the $I C C P R$ provides specifically that "[i]n the determination of ... rights and obligations in a suit at law, everyone shall be entitled to a fair and public hearing by a competent, independent and impartial tribunal established by law." ${ }^{60}$

The UDHR, ICCPR and ICESCR also contemplate other potentially relevant rights, including: the right to own property and the right not to be arbitrarily deprived thereof; ${ }^{61}$ the adequate protection of the home; ${ }^{62}$ safe and healthy working conditions, ${ }^{63}$ an adequate standard of living, including the "continuous improvement of living conditions", ${ }^{64}$ the highest attainable standard of physical and mental health, including the improvement of all aspects of environmental and industrial hygiene $;{ }^{65}$ and access to the enjoyment and utility of natural resources. ${ }^{66}$ Other relevant rights include labour rights and the right to freedom from

19 December 1966, GA Res. 2200A(XXI), UN Doc. A/6316(1966), 999 U.N.T.S. 171, Can. T.S. 1976 No. 47, 6 I.L.M. 368 (entered into force 23 March 1976, accession by Canada 19 May 1976). (entered into force 3 January 1976).

Charlesworth \& Chinkin, supra note 38 at 202. As C. Raj Kumar has recently commented, these human rights instruments - including the UDHR, ICCPR and ICESCR - have "acquired greater legitimacy in the last few decades as more and more nations have realised the importance of these human rights as instruments for better governance" ("Corruption and Human Rights: The Human Right to a Corruption-Free Service - Some Constitutional and International Perspectives" Frontline 19:19 (14-27 September 2002)).

It is this right that is largely at issue in the context of the discussion in Part IV of this article.

$U D H R$, supra note 51, art. 8 .

$I C C P R$, supra note 54 , art. 2(3), as commented on - in the context of civil human rights litigation in Stephens, "Translating Filártiga," supra note 22 at 47.

Ibid., art. 14. For a recent judicial discussion of this article in Canada, see Bouzari v. Iran, [2002] O.T.C. 297 (Ont. Sup. Ct.) at para. 68 [Bouzari].

$U D H R$, supra note 51 , art. 17(2).

$I C C P R$, supra note 54 , art. 17(1).

ICESCR, supra note 55 , art. $7($ b).

Ibid., art. $11(1)$. See also UDHR, supra note 51, art. 25(1).

ICESCR, supra note 55, art. 12.

ICCPR, supra note 54, art. 47: ICESCR, supra note 55. arts. 1(2), 25. 
discrimination in the workplace. ${ }^{67}$ Additionally, other international and regional human rights regimes and initiatives contemplate similar rights and remedies. ${ }^{68}$

Finally, the rights to assemble and protest with respect to violations of these basic human rights constitute further rights that need to be protected. ${ }^{69}$ There are numerous examples around the world in which basic rights have been violated, and then protests of those violations have been shut down, often violently and with governmental and/or corporate awareness or support. ${ }^{70}$

These are the kinds of international human rights that are contemplated by this project. More specifically, they are of the kinds that are increasingly involved — often negatively in the context of commercial globalization. It is these rights that will be discussed, through their relation to civil procedure, in Part IV of this article.

\section{B. CORPORATE CODES OF CONDUCT}

In addition to the principles and rights set out in the international bill of rights, a further initiative aimed at governing, among other things, the impact of MNCs on international human rights, is the creation of voluntary corporate codes of conduct. For example, and perhaps most notably, U.N. Secretary-General Kofi Annan proposed the Global Compact at the 1999 World Economic Forum. As he stated at that meeting:

[g]lobalization is a fact of life. But I believe we have underestimated its fragility. The problem is this. The spread of markets outpaces the ability of societies and their political systems to adjust to them, let alone to guide the course they take. History teaches us that such an imbalance between the economic, social and political realms can never be sustained for very long....

See e.g. International Labour Organization (ILO), Tripartite Declaration of Principles Concerning Multinational Enterprises and Social Policy (1978), 17 I.L.M. 423, as amended ILO GB.279/MNE/1 279th Session (November 2000) [ILO Tripartite Declaration]. Earlier amendments were also made at the 246th Session of the ILO Governing Body in Geneva in November 1995. See also the useful list of international labour conventions and recommendations referred to in the Annex of the ILO Tripartite Declaration. For recent commentary, see Phillipa Weeks, "Labour Law and Human Rights" in Bottomley \& Kinley, supra note 28 at 281.

See e.g. the American Convention on Human Rights, 22 November 1969, OAS Doc. OEA/Ser. L/V/II.50 (1980) (entered into force 18 July 1978); the European Convention for the Protection of Human Rights and Fundamental Freedoms, 4 November 1950, 213 U.N.T.S. 221, Eur. T.S. 5 [ECHR]; and the African Charter on Human and Peoples' Rights, 27 June 1981, OAU Doc. CAB/LEG/67/3 Rev. 5, (1982), 21 I.L.M. 58 (entered into force 21 October 1986). See also the Declaration on the Right and Responsibility of Individuals, Groups and Organs of Society to Promote and Protect Universally Recognized Human Rights and Fundamental Freedoms, adopted 9 December 1975, GA Res. 53/144, Annex.

See e.g. UDHR, supra note 51, arts. 18-20; ICCPR, supra note 54, arts. 18-19, 21; and ICESCR, supra note 55 , art. 8

For example, as reported by Human Rights Watch, approximately 3,000 tons of Taiwanese toxic waste were dumped in a field in the Cambodian port of Sihanoukville in November 1998. After the local villagers either fell ill or died as a result of the waste, several days of protests were held largely blaming the government for the event. Arrests of protesters followed (see Human Rights Watch, "Toxic Justice: Human Rights, Justice and Toxic Waste in Cambodia," online: Human Rights Watch <www.hrw.org/ reports/1999/cambotox/camb0996.htm\#P55_890>). For a general source for other similar reports, sec Human Rights Watch, "Corporations \& Human Rights," online: Human Rights Watch < www.hrw.org/ corporations/>. See also generally Human Rights Watch. "World Report 2003," online: Human Rights Watch <www.hrw.org/wr2k3/ issues5.html>. 
Our challenge today is to devise a ... compact on the global scale, to underpin the new global economy. If we succeed in that, we would lay the foundation for an age of global prosperity, comparable to that enjoyed by the industrialized countries in the decades after the Second World War. Specifically, I call on you individually through your firms, and collectively through your business associations - to embrace, support and enact a set of core values in the areas of human rights, labour standards, and environmental practices. ${ }^{71}$

The Global Compact was formally launched at the U.N. Headquarters in New York on 26 July 2000. Essentially, the Global Compact is an international initiative designed to bring companies together with U.N. agencies and labour and civil society stakeholders to support fundamental human rights, labour, and environment principles. ${ }^{72}$ While not binding in nature, it does encourage a broad-based corporate participation in the international human rights initiative. At present, the model largely contemplates companies reporting their human rightsrelated activities and initiatives in their annual reports. ${ }^{73}$

Other non-binding initiatives aimed at the regulation of corporate activity and its impact on human rights around the world - while "uncertain" and not "conclusive" been experimented with and implemented. ${ }^{75}$ Most recently, a U.N. sub-committee - the Working Group on the Working Methods and Activities of Transnational Corporations prepared the Draft Norms on the Responsibilities of Transnational Corporations and Other Business Enterprises with Regard to Human Rights. ${ }^{76}$ This document is primarily designed to "provide a sensible way to operationalise the broad references to human rights principles in the Global Compact," sector's respect for human rights." ${ }^{78}$ As Stephens has argued, general corporate compliance with international human rights norms is a key element of these voluntary codes. ${ }^{79}$

71 "A Compact for the New Century," online: United Nations <www.un.org/news/press/docs/1999/ 199020/sgsm6881.html>.

72 See the U.N., "The Global Compact," online: U.N. Global Compact <www.unglobalcompact.org/ Portal/default.asp>. For a recent discussion of the Global Compact, see S. Prakash Sethi, Setting Global Standards: Guidelines for Creating Codes of Conduct in Multinational Corporations (Hoboken, NJ: John Wiley \& Sons, 2003) at 110-34.

See e.g. Amnesty International, "Letter to Louise Fréchette Raising Concerns on UN Global Compact" (7 April 2003), online: Amnesty International <www.web.amnesty.org/web/web.nsf/pages/ec-briefings global_7April03> ["Letter to Louise Fréchette"]. Kindred et al., supra note 43 at 51-52.

75 See e.g. UN Code on Restrictive Business Practices (1981), 19 I.L.M. 813; World Bank Guidelines on the Treatment of Foreign Direct Investment (1992), 31 I.L.M. 1363; Draft UN Code of Conduct on Transnational Corporations (1984), 23 I.L.M. 626; ILO Tripartite Declaration, supra note 67; Uniform Code on Andean Multinational Enterprises (1991), 30 I.L.M. 1296; and OECD Guidelines for Multinational Enterprises (1976), 15 I.L.M. 967. These OECD Guidelines have been subsequently revised, including in 1979, 1991 and 2000. For general commentary on these international code initiatives, see e.g. Mendes \& Mehmet, supra note 3 at 129-150; Kindred et al., supra note 43 at 51-52; and Louis Henkin et al., International Law, Cases and Materials, 3d ed. (St. Paul, MN: West Publishing, 1993) at 368-73. UN Doc. E/CN.4/Sub.2/2002/13, Annex (April 2003).

77 Amnesty International, "Amnesty International and the United Nations Global Compact," online: Amnesty International <www.web.amnesty.org/web/web.nsf/pages/ec_briefings_water>.

$78 \quad$ "Letter to Louise Fréchette," supra note 73.

7. "The Amorality of Profit," supra note 23 at ff. V.C, notes 193-202 and surrounding text. See generally C. Raj Kumar, "Human Rights Accountability of Transnational Corporations and Business Enterprises - Governance Perspectives" (2003) 6 Corp. Gov. Int'I 15; and Christiana Ochoa, "Advancing the Language of Human Rights in a Global Economic Order: An Analysis of a Discourse" (2003) 23 B.C. Third World L.J. 57. 
While none of these codes is currently binding, they do demonstrate a movement toward corporate accountability for human rights-related matters that seems currently to be gaining strength and momentum. They also provide further support for the application of broad international human rights principles to corporate activity around the world. It is this application - of international human rights standards to private actors - that is discussed in the next section of this article.

\section{APPLICATION TO INDIVIDUALS AND CORPORATIONS}

It is important to recognize that the international bill of rights, as supported by voluntary codes, provides for the promotion of human rights not only by states, but also by individuals as well. For example, the $U D H R$ provides that, in addition to states, "every individual and every organ of society ... shall strive ... to promote respect for these rights and freedoms and ... to secure their universal and effective recognition and observance." ${ }^{80}$ Similarly, like the $U D H R$, both the ICCPR and ICESCR include in their preambles that "the individual, having duties to other individuals and to the community to which he [or she] belongs, is under a responsibility to strive for the promotion and observance of the rights recognized in the present Covenant." $" 81$

And to the extent that the international bill of rights applies to individuals, it has been interpreted also to apply to corporations. As Louis Henkin has commented: "[e]very individual includes juridical persons. Every individual and every organ of society excludes no one, no company, no market, no cyberspace. The Universal Declaration applies to them all." ${ }^{82}$ Further, as Stephens has argued, "[c]orporations are independent legal entities, subject to international and domestic regulation and capable of being held legally accountable for their actions. When an international agreement applies broadly to all actors, it applies to corporations as well." ${ }^{83}$ In this line of thinking, Stephens has further argued that:

[t]he international community has determined over the past fifty years that certain actions are prohibited and constitute violations of international law.... Most of the international agreements that codify these and other human rights obligations are addressed to states, calling on states to enforce the listed obligations. But the norms embedded in the agreements bind the behavior of private individuals and corporations alike. International law has never been limited to regulating state behavior. Over the past fifty years, the international community has moved decisively to expand not only the rights of non-state actors but their responsibilities as well. $^{84}$

UDHR, supra note 51 , preamble.

The same text is found in both documents: ICCPR, supra note 54, preamble, ICESCR, supra note 55, preamble. My thoughts on this aspect of the discussion have been influenced by Beth Stephens. See Stephens, "The Amorality of Profit," supra note 23 at ff. V.B.1.

"The Universal Declaration at 50 and the Challenge of Global Markets" (1999) 25 Brooks J. Int'l L. 17 at 25 , cited in Stephens, ibid. at ff. V.B.3, note 181 and accompanying text. David Kinley has also recognized, more recently, that it is "widely accepted" that "organs of society" include "private bodies of which corporations are quintessential examples," ("Human Rights as Legally Binding or Merely Relevant?" in Bottomley \& Kinley, supra note 28 at 38 ).

Stephens, "The Amorality of Profit," supra note 23 at ff. V.B.3, notes 181-82 and surrounding text.

Ibid. at ff. V.B, note 141 and surrounding text [citations omitted]. 
Further, specific rights contemplated by the international bill of rights have been argued to apply to corporations as well as to individuals. As Bell has argued, the right of "access to a court," the "opportunity for a fair hearing" and the "right to freedom of expression" ought to and/or do "extend to corporations." ${ }^{.85}$ In the case of the Bhopal disaster, for example, in addition to the right to a fair and public hearing, ${ }^{86}$ other rights might be seen to apply, including: the right not to be arbitrarily deprived of property; adequate protection of the home; safe and healthy working conditions; adequate standards of living conditions; the highest attainable standard of physical and mental health, including the improvement of all aspects of environmental and industrial hygiene; and access to the enjoyment and utility of natural resources. ${ }^{87}$

However, notwithstanding the broad inclusive language of the international bill of rights, the application of specific international human rights norms to private actors - most notably to corporations - continues to be a controversial project in this era of commercial globalization. As mentioned above ${ }^{88}$ international law traditionally has been thought of as a regulatory framework for states. Rights claims and protections - to the extent that they are governed by international documents - are still largely available to individuals through states ${ }^{89}$ or to individuals against states. ${ }^{90}$ This includes proceedings brought by states or individuals in international tribunals or in domestic tribunals involving state actors. ${ }^{91}$ There is still considerable resistance to human rights claims - based on international human rights regimes - being made available directly against individuals, particularly in domestic tribunals.

However, recognition of the important application of international human rights norms to individuals and corporations, together with the evolution of codes of conduct, ${ }^{92}$ shows that this resistance is changing. As McCorquodale has rightly commented, while "international legal obligations on [MNCs] ... to protect human rights are not yet firmly in place ... this is beginning to change.... It is certain that during the course of the twenty-first century ... the

Andrew S. Bell, "Human Rights and Transnational Litigation - Interesting Points of Intersection" in Bottomley \& Kinsley, supra note 28 at 115 [Bell, "Hunan Rights and Transnational Litigation"]

Discussed supra Part III.A.2, notes 58-60 and accompanying text.

Ibid., notes 61-66 and accompanying text.

Supra Part III, notes 37-40 and accompanying text.

See e.g. Steiner \& Alston, supra note 31 at 1082-128.

See e.g. Toonen v. Australia (1994), 1-3 Int. H.R. Rep. 97, cited in Kindred et al., supra note 43 at 77477.

Note, however, that - to the extent that a given international human rights regime applies in Canada - foreign states are immune from the jurisdiction of any Canadian court except as provided for in the State Immunity Act, R.S.C. 1985, c. S-18. See e.g. Aristocrat v. National Bank of the Republic of Kazakhstan (2001), 21 C.P.C. (5th) 147 (Ont. Sup. Ct. J.) C.C.S. No. 20984 (Ont. Sup. Ct.) [Aristocrat]; Bouzari, supra note 60 at para. 55, Canada Labour Code (Re), [1992] 2 S.C.R. 50. Further, however, to the extent that the State Immunity Act requires a suit to be pursued in a foreign jurisdiction - for example on grounds of forum non conveniens - and further, if that foreign jurisdiction were unable to provide a "fair hearing," then s. 2 of the Canadian Bill of Rights, S.C. 1960, c. 44, reprinted in R.S.C. 1985, App. III, likely would act to make the State Immunity Act inoperative in the given case. See e.g. Aristocrat, ibid. at paras. 29-34, Granger J. See also Old St. Bonafice Residents Assn. Inc. v. Winnipeg (City), [1990] 3 S.C.R. 1170, Sopinka J. 
activities of [MNCs] ... that violate human rights will be subject to international and national legal regulation." 93

This article does not purport to provide a comprehensive treatment of the recent move towards private enforcement of international human rights regimes. ${ }^{94}$ However, I rely on the proposition that international human rights tools are becoming increasingly engaged by the actions of private actors - specifically $\mathrm{MNCs}$ - in the context and wake of commercial globalization. ${ }^{95}$

When it comes to looking at globalization - specifically commercial globalization through the affairs of MNCs - there is clearly more than just money involved. As the Bhopal disaster demonstrated, our globalized economy and private commercial affairs are often doing damage to fundamental rights and interests of individuals around the world. ${ }^{96} \mathrm{As}$ the Lawyers Committee for Human Rights has argued: "[w]ith the rapid growth of the global economy in the last twenty years, the linkages between human rights, trade, the labor movement, and the activities of multinational corporations have taken on new importance." 97

Again, as the Bhopal disaster demonstrates, this impact is acutely troubling in the developing world. As one report has indicated, "[d]eveloping countries ... are particularly vulnerable ... they compete globally to attract multinational companies for their investment and capital, and in this process, often tend to ignore the safety and health violations that many MNC[]s engage in." 98 Similarly, Jamie Cassels has commented that developing nations:

confer upon $\mathrm{MNC}[\mathrm{s}$ a competitive advantage because they offer low-cost labor, access to markets, and lower operating costs. Once there, companies have little incentive to minimize environmental and human risks. Lax environmental and safety regulation, inadequate capital investment in safety equipment, and poor communications between companies and governments compound the problem. ${ }^{99}$

Given these concerns, calls are being made for further corporate responsibility for international human rights violations. For example, Amnesty International has argued that MNCs:

have a responsibility to contribute to the promotion and protection of human rights. In an increasingly globalized world economy, their decisions and actions impact directly on governmental policies and on the enjoyment of human rights. The Universal Declaration of Human Rights calls on "every individual and every organ of society" to play its part in securing universal observance of human rights. Companies and financial

Supra note 28 at 114.

For a useful discussion of these issues, see e.g. Kinley, supra note 82 at 40-44.

See e.g. Stephens, "The Amorality of Profit," supra note 23 at ff. V.B.1.

For a useful discussion on the "century of the corporation," arguing that "the corporate form now dominates every aspect of our lives," see Jonathan Clough \& Carmel Mulhern, The Prosecution of Corporations (South Melbourne: Oxford University Press, 2002) at 1.

Business and Human Rights in Steiner \& Alston, supra note 31 at 1353.

TED Case Studies, "Bhopal Disaster" (1997), online: American University Mandela Projects <www. american.edu/TED/bhopal.htm> ["Bhopal Disaster"]. I am grateful to C. Raj Kumar for bringing this study to my attention.

The Uncertain Promise of Law: Lessons from Bhopal (Toronto: University of Toronto Press, 1993) at 279, cited in "Bhopal Disaster," ibid. See also Stephens, "The Amorality of Profit," supra note 23 at ff. VI, note 209 and accompanying text. 
institutions are organs of society, and as their operations come under scrutiny around the world, this is increasingly demanded by consumers, shareholders and the communities with whom they interact. ${ }^{100}$

As such, as Amnesty International concluded, "[a]ll companies have a direct responsibility to respect human rights in their own operations." ${ }^{101}$ Mary Robinson similarly commented that:

[b]ig corporations have the power to bring great benefits to poor communities - but they can cause great damage too: through degradation of the environment, exploitation of economically weak communities, the use of child labour. In recent years there has been an increasing awareness on the part of business that it must face up to its responsibilities in the human rights field. ${ }^{102}$

These concerns, particularly in relation to MNC activity in the developing world, have led to the creation and promotion of international corporate codes of conduct ${ }^{103}$ and the call for the application of international human rights regimes to be applied to the activities or MNCs. ${ }^{104}$

Charlesworth and Chinkin have pointed out that "[t]he two major challenges to all human rights ... in the twenty-first century will be the forces of religious extremism and of economic globalization." ${ }^{05}$ Specifically with respect to economic globalization, domestic laws need to be drafted and interpreted to accommodate these challenges. As Castel and Walker have further commented: "Now that international law is increasingly applicable to matters once thought subject only to national laws, new rules may have to be fashioned." 106

Essentially, therefore, what is at issue here is the ever-expanding "privatization" of international human rights in the context of commercial globalization: the move that has allowed "domestic courts [to] operate as a public conduit for the flow of international human rights obligations into the private sphere." 107 This move toward the privatization of international human rights by their application to MNCs through domestic courts is, in my view, of growing and critical importance in the work of civil procedure. Regulating disputes involving this convergence of globalization and international human rights through tools of civil procedure is thus the subject of Part VI of this article.

Human Rights Principles for Companies (January 1998), Amnesty International Index: ACT 70/01/98 in Steiner \& Alston, supra note 31 at 1351 [Human Rights Principles for Companies].

Ibid.

"Constructing an International Financial, Trade and Development Architecture: The Human Rights Dimension" (1 July 1999) cited in ibid. at 1313.

Discussed supra Part III.B.

See e.g. Human Rights Principles for Companies, supra note 100 at 1351; Stephens, "The Amorality of Profit," supra note 23 at ff. V.B, note 141 and accompanying text. Supra note 38 at 249.

Jean-Gabriel Castel \& Janet Walker, Canadian Conflict of Laws, 5th ed. (Markham, Ont.: Butterworths Canada Ltd., 2002) at 35-25 [citations omitted].

Kinley, supra note 82 at 40. 


\section{Civil Procedure}

\section{A. Globalization and Domestic Civil Courts}

The modern atmosphere in which the civil justice system operates has become increasingly international. According to La Forest J., "[t] he business community operates in a world economy and we correctly speak of a world community even in the face of decentralized political and legal power." 108 Similarly, as Cumming J. recently acknowledged, "[a]s a result of the inexorable forces of globalization and expanding international free trade and open markets, there will be an ever-increasing inter-jurisdictional presence of corporate enterprises." 109

As a result of this modern, globalized atmosphere, ${ }^{110}$ it is clear that the business of domestic litigation has also become increasingly international. While this article does not attempt to provide statistical support for this proposition ${ }^{111}$ in terms of the internationalization of cases and litigants before the courts, there is no lack of support from judges, ${ }^{112}$ academics, ${ }^{113}$ or the bar ${ }^{114}$ for this statement. ${ }^{115}$ For example, Sopinka J. commented, as set

Morguard Investments Ltd. v. De Savoye, [1990] 3 S.C.R. 1077 at 1098 [Morguard].

VitaPharm Canada Ltd. v. F. Hoffmann-La Roche Ltd. (2001), 11 C.P.R. (4th) 230 at para. 27 (Ont. Sup. Ct.), aff'd (2002), 18 C.P.R. (4th) 267 (Ont. Sup. Ct.) [VitaPharm cited to C.P.R.]. See also recently Shane v. JCB Belgium N.V., [2003] O.J. No. 4497 (S.C.) at para. 24 (QL), Smith J.

For a discussion of globalization in the context of this article, see generally supra Part II.

Based on the background research for this project, it is clear that further empirical research and analysis is needed in tracking the business of our civil dispute resolution system. I am grateful for the research assistance on this point of both Michael Storozuk from the University of Alberta Weir Memorial Law Library and Michael Lines from the Canadian Forum on Civil Justice. For a further discussion on this issue, see Report of the Canadian Bar Association, Task Force on Systems of Civil Justice (1996), recommendations 51-52.

See supra notes 108-109 and accompanying text, and further, infra notes 116, 119-26 and accompanying text. See also Beals v. Saldanha, 2003 SCC 72 at paras. 27-28, Major J. [Beals]; and Hunter v. Namco Prehung Doors and Windows Ltd. (c.o.b. Pemberton Door and Window), 2003 BCSC 1015 at para. 9, Crawford J.

For example, as one commentator has recently stated, "[t]he emergence of an ever more integrated global economy has obvious ramifications for transnational litigation....Quite simply, more international trade means more transnational disputes, contractual, quasi-contractual, and arising from the negligent provision of goods and services" (Bell, Forum Shopping, supra note 29 at 4). Harold H. Koh further stated that: "Like it or not, foreign disputes are going to come into our courts. And if they raise issues of concern to us, our courts ought to be able to adjudicate those concerns" (cited in A. Liptak "U.S. Court's Role in Foreign Feuds Comes Under Fire" The New York Times (3 August 2003) A1). See also Janet Walker, "International Dispute Resolution in the 21 st Century: The Revitalization of National Courts" in Canadian Council on International Law, ed., Looking Ahead: International Law in the 21st Century (The Hague: Kluwer Law International, 2002) 95 at 95 [Looking Ahead].

For example, in a litigation-related report from Ontario, it was stated that "[i]t's an accepted fact: Lawyers today practice in an increasingly complex world....Forces such as ... globalization ... are fundamentally changing the face of litigation practice." See Lawyers' Professional Indemnity Company (Ontario), Special Report from LPIC: Litigation Claims Exceed Real Estate Claims, Lawyer Conduct is Deteriorating, All Practitioners Should Be Alarmed (Summer 2000) (document on file with author). Further, one of Canada's largest law firms recently commented that the "North American Free Trade Agreement has substantially increased the amount of business transacted between Americans and Canadians. A by-product of this increase in business has been an increase in litigation on both sides of the border" (Paul F. Monahan, "U.S. Litigation and Canadian Witnesses: Taking Evidence in Canada" in Fasken Martineau DuMoulin LLP, Litigation Bulletin (September 2001) 1 at 1). See also Julius Melnitzer, "Litigation Goes Continental" Lexpert (November/December 2003) 68 at 68.

The impact of globalization is not limited to the litigation context. For example, in a report from the 
out at the beginning of this article, that "the business of litigation, like commerce itself, has become increasingly international." "16 Further, as Janet Walker has argued, in the first few decades of the twenty-first century, national courts will "re-establish[] their primacy as fora for dispute resolution, including international dispute resolution." 117

As a result of the internationalization of cases and litigants before domestic courts largely resulting from commercial globalization - the interpretation of domestic procedural laws in turn has become of increased interest and importance. For example, Sopinka J., citing Dicey and Morris, ${ }^{118}$ acknowledged that issues of domestic process ${ }^{119}$ have become more significant in our modern economy: "This topic has become of increasing modern importance as a result of a variety of factors including the greater ease of communication and travel; the tendency of courts in many countries to extend their jurisdiction over events and persons outside their territory; and a greater awareness of foreign laws and procedures." 120

Therefore, according to La Forest J., "[m]odern states ... cannot live in splendid isolation.... Accommodating the flow of wealth, skills and people across state lines has now become imperative." ${ }^{21}$ For this reason, the "content" of domestic laws "must be adjusted in the light of a changing world order." 122

In essence, judges have now been mandated, when interpreting domestic procedural laws, to take into account - and more specifically, to "[a]ccommodate[]"123 - the pressures and resulting "changing world order" 124 brought by the "ever-increasing inter-jurisdictional

Law Society of British Columbia to the Federation of Law Societies of Canada, it was documented that the "globalization of practice" was identified by B.C. lawyers as one of the "chief challenges" facing the legal profession "over the next five years." See Law Society of British Columbia, 2000-2001 Report to the Federation (6 July 2001) (document on file with author). Further, according to a recent report: "for major Canadian law firms, the provision of cross-border legal services is now the number one strategic issue" (Richard Potter, "The Canada/U.S. Market" Lexpert (June 2003) 62 at 68).

For general statistical discussions, see e.g. Industry Canada, Global Trends: 1980-2015 and Beyond by J. Bradford De Long (Ottawa: Industry Canada, 1998), online: Industry Canada <www.strategis. ic.gc.ca/SGG/ra0174/e.html>; Industry Canada, North American Economic Integration: 25 Years Backward and Forward, Gary C. Hufbauer \& Jeffry J. Schott (Ottawa: Industry Canada, 1998), online: <strategis.ic.gc.ca/SSG/ra017/oe.html>.

Amchem, supra note 1 at 333. See also Recherches Internationales Québec v. Cambior Inc., J.E. 981905 (S.C.) (QL) [Recherches Internationales]. Walker, supra note 113 at 95 .

118 A.V. Dicey \& J.H.C. Morris, The Conflict of Laws, 11 th ed., vol. 1 (London: Sweet \& Maxwell, 1987) at 391. See now L. Collins, ed., Dicey and Morris on the Conflict of Laws, 13th ed. (London: Sweet \& Maxwell, 2000).

Specifically including, in the context of Sopinka J.'s decision in Amchem, issues of private international law.

Amchem, supra note 1 at $324-25$.

Morguard, supra note 108 at 1097-98.

Ibid. at 1097. See also the Australian High Court's recognition that procedural conflict of laws issues - specifically including forum non conveniens - are increasingly influenced by "the modern world, particularly ... the modern commercial world" (Voth v. Manildra Flour Mills Pty. Ltd. (1990), 171 C.L.R. 538 at 586, Toohey J.). For a useful discussion on the role of private law and private international law in an era of globalization, see Robert Wai, "Transnational Liftoff and Juridical Touchdown: The Regulatory Function of Private International Law in an Era of Globalization" (2002) 40 Colum. J. Transnat'I L. 209. 
presence of corporate enterprises." ${ }^{25}$ Or, put another way, according to Sopinka J., "parochial" judicial attitudes are "no longer appropriate."126

In the context of this article, this judicial mandate is equally significant. When considering domestic cases involving potential international human rights elements, interpretations of local procedural rules need to be acutely aware of, and open to, the potential negative impacts of commercial globalization, largely in the form of the "ever-increasing interjurisdictional presence" of MNCs. Judicial "parochial[ism]" is clearly not "appropriate." In light of increased global pressures, domestic processes need to be seen as tools of power that increasingly and dramatically affect the decisions and lives of individuals beyond the limited jurisdiction of the forum state. Here is where the intersection of globalization, ${ }^{127}$ international human rights ${ }^{128}$ and civil procedure comes alive.

There are several elements of the general topic of "civil procedure" that are implicated in this discussion. ${ }^{129}$ In Part IV.B, I look primarily at procedural issues involving jurisdiction. I then, in Part IV.C, briefly discuss several other procedural tools - including class actions, the recognition of foreign judgments, and discovery in extraterritorial jurisdictions - that are becoming increasingly important in the context of regulating the impact of commercial globalization on international human rights through domestic civil courts. ${ }^{130}$ All of these

VitaPharm, supra note 109 at para. 27.

Amchem, supra note 1 at 334 . With respect to this judicial interpretive mandate, Vaughan Black has argued - through the recognition by the Supreme Court of Canada of the "momentous change in the world economic order and its attendant effects on political power" - that the Court is in fact pronouncing that "judges, in articulating the common law, should attempt to facilitate global capitalism" ("Commodifying Justice for Global Free Trade: The Proposed Hague Judgments Convention" (2000) 38 Osgoode Hall L.J. 237 at 249 and n. 45). See also Beals, supra note 112 at paras. 27-28, Major J. and paras. 163-74, LeBel J., dissenting.

Supra Part II.

Supra Part III.

In choosing these specific procedures, I have been influenced by the following statement by Sopinka

J., made in the context of a jurisdictional challenge, which contemplates a number of these procedures:

With the increase of free trade and the rapid growth of multi-national corporations it has become more difficult to identify one clearly appropriate forum.... The defendant may not be identified with only one jurisdiction. Moreover, there are frequently multiple defendants carrying on business in a number of jurisdictions and distributing their products or services world-wide. As well, the plaintiffs may be a large class residing in different jurisdictions. It is often difficult to pinpoint the place where the transaction giving rise to the action took place. Frequently, there is no single forum that is clearly the most convenient or appropriate for the trial of the action....In some jurisdictions, novel principles requiring joinder of all who have participated in a field of commercial activity have been developed for determining how liability should be apportioned among defendants. In this climate, courts have had to become more tolerant of the systems of other countries (Amchem, supra note 1 at 333-34).

Some of the tools discussed in Parts IV.B-C of this article - particularly those related to jurisdiction - although properly part of this discussion, are equally issues of private international law or conflict of laws. The term "private international law" is often thought to include "conflict of laws" or choice of law principles. As Joel Paul has outlined, these private "principles" consist of "domestic legal principles that determine jurisdiction to prescribe, enforce and adjudicate claims involving foreign interests or persons" ("The Isolation of Private International Law" (1988) 7 Wis. Int'l L.J. 149 at 150 note 2) (Paul, "Isolation"]. Although the phrases "conflict of laws" (typically in the U.S.) and "private international law" (in Europe, although coined in the U.S.) are often used interchangeably - see e.g. Marvin Baer et al., eds., Private International Law in Common Law Canada: Cases, Text, and Materials (Toronto: Emond Montgomery Publications Limited, 1997) at 3 - private international law, particularly after 1945, expanded its scope, in response to expanding international business and trade, to include other 
procedural tools have been chosen as examples of how civil procedure has become a gatekeeper to the access of meaningful justice - through the protection and/or recognition of basic rights and liberties - for parties involved in civil matters with multi-jurisdictional contacts.

\section{B. JURISDICTION}

Perhaps the most important area of civil procedure to be involved in this intersection with globalization and international human rights is jurisdiction. As one commentator has recently argued in the context of the "challenges posed ... by the forces of globalization," the "reality of human interaction is chafing against the strictures our current conception of legal jurisdiction imposes." ${ }^{\prime 31}$

Jurisdictional determinations in civil procedure typically involve several questions. ${ }^{132}$ Does a domestic court have jurisdiction over a matter? If so, is the domestic jurisdiction the appropriate forum - forum conveniens - to hear the case? ${ }^{133}$ A related but "more

areas such as "international business transactions," "international policy" and "comparative law." See David Kennedy, "The Disciplines of International Law and Policy" (1999) 12 Leiden J. Int'l L. 9 at 32 33; and Symeon C. Symeonides, Wendy Collins Perdue \& Arthur T. von Mehren, Conflict of Laws: American, Comparative, International, Cases and Materials (St. Paul, Minn.: West Group, 1998) at 5:

Berman, supra note 20 at 544 . For a useful general discussion of jurisdiction and related matters, see C.A. Kent \& C.A. Coe, "Conflicts, Choice of Forum, Coordination and Other Issues" in Participatory Justice, supra note 30.

For general treatments of jurisdictional principles in Canada, see e.g. Amchem, supra note 1 at 334; Morguard, supra note 108 at 1102-104, 1108-109; Tolofson v. Jensen; Lucas (Litigation Guardian of) v. Gagnon, [1994] 3 S.C.R. 1022 at 1049, 1058, 1065-66, La Forest J. [Tolofson]; Hunt v. T\& N plc, [1993] 4 S.C.R. 289 at 325-26, La Forest J. [Hunt]; and Moran v. Pyle National (Canada) Ltd., [1975] 1 S.C.R. 393. See also recently Spar Aerospace Ltd. v. American Mobile Satellite Corp. (2002), 220 D.L.R. (4th) 54 at paras. 14-23 (S.C.C.); Beals, supra note 112; Incorporated Broadcasters Ltd. v. Canwest Global Communications Corp. (2003), 63 O.R. (3d) 431 at 444-57 (C.A.), Rosenberg J.A. [Incorporated Broadcasters]; Muscutt v. Courcelles (2002), 60 O.R. (3d) 20 at 27-36 (C.A.), Sharpe J.A. [Muscutt]; Duncan (Litigation Guardian Of) v. Neptunia Corp. (2001), 53 O.R. (3d) 754 (Sup. Ct.), Wright J.; and Banff Transportation and Tours Inc. v. Buchan, 2002 ABQB 764 at paras. 10-13, 24-25, Hawco J., aff'd 2002 ABCA 218. In England, see e.g. Spiliada Maritime Corp. v. Cansulex Ltd., [1987] A.C. 460 (H.L.) [Spiliada]; Lubbe v. Cape plc, [2000] 1 W.L.R. 1545, 259 N.R. 18 (H.L.) [Lubbe cited to N.R.]; and Airbus Industrie G.I.E. v. Patel, [1999] 1 A.C. 119 (H.L.). In the U.S., see e.g. Piper Aircraft Co. v. Reno, 454 U.S. 235 (1981) [Piper]; and Union Carbide, supra note 2.

In Canada, these jurisdictional questions are primarily governed by provincial rules of civil procedure typically regulating service ex juris and related matters. Most provinces have permissive rules that generally do not require leave for service ex juris. See e.g. Ontario, Rules of Civil Procedure, r. 17, British Columbia, Rules of Court, r. 13, and Saskatchewan, The Queen's Bench Rules, r. 31. Alberta, on the other hand, currently requires a court order for service ex juris. See Alberta Rules of Court, $\mathrm{r}$. 30. See also the Hague Convention on the Service Abroad of Judicial and Extrajudicial Documents in Civil and Commercial Matters, 15 November 1965, Can. T.S. 1989 No. 2 (entered into force 10 February 1969, accession by Canada 1 May 1989). Fundamentally, however, these questions are governed by the constitutional principles of "order and fairness" and "real and substantial connection" (see Morguard, supra note 108 at 1097, 1102, 1104-107). See also Muscutt, supra note 132 at 36-37. These questions are also governed by the international law doctrine of comity (see e.g. Amchem, supra note 1 at 335-37; and Beals, supra note 112 at paras. 27-28). For a useful discussion of the principle of "comity," see e.g. Paraschos v. YBM Magnex Int'l, Inc., 130 F.Supp. 2d 642 at 644 (E.D. Pa. 2000), Newcomer S.J., reconsideration den'd [2001] U.S. Dist. LEXIS 22790 (E.D. Pa. 2001) (Lexis) [Paraschos]:

[T]he principle of international comity, also known as the "comity of nations doctrine," permits 
aggressive" jurisdictional remedy is the anti-suit injunction. ${ }^{134}$ The Ontario Court of Appeal recently described these issues of jurisdiction, in the context of civil procedure, as emerging from a "rapidly evolving area of law." 135 As the Court stated:

Until the early 1990s, this area was governed by a set of rigid common law rules developed in England in the 19 th century. These rules ... were shaped by the sovereignty concerns of a dominant 19 th-century world power anxious to safeguard its territorial sovereignty and jealous of any attempt by foreign states to intrude.

Towards the end of the 20th century, it became increasingly apparent that these rules were out of keeping with the reality of modern interprovincial and international commerce and the frequent and rapid movement of people, goods and services across borders. ${ }^{136}$

Again, the theme of power is raised. The question of whether a court is willing to grant or deny jurisdiction over a given cause of action or litigant becomes, in the end, a question of power. Because different justice will be dispensed in different jurisdictions, the decision to afford or deny jurisdiction is a threshold decision that ultimately may mean the difference between meaningful justice gained and meaningful justice denied. ${ }^{137}$ As Berman has argued, "[a]n assertion of jurisdiction, therefore, is never simply a legal judgment, but a socially embedded, meaning-producing act." 138

the "recognition of foreign proceedings to the extent that such proceedings are determined to be orderly, fair and not detrimental to the nation's interests." Pravin Banker Assocs., Ltd. v. Banco Popular del Peru, 165 B.R. 379, 384 (S.D.N.Y. 1994). The Supreme Court in Hilton v. Guyot, 159 U.S. $113,164 \ldots$ (1895) defined international comity as: "the recognition which one nation allows within its territory to the legislative, executive or judicial acts of another nation, having due regard both to international duty and convenience, and to the rights of its own citizens or of other persons who are under the protection of its laws.

The U.S. Supreme Court's definition of comity in Hilton, referred to in Paraschos, was also "prefer[ed]" by La Forest J. in Morguard, supra note 108 at 1096 as "the more complete formulation of the idea of comity."

134 Amchem, ibid. at 334. This remedy is thought of as more aggressive given that it is "more intrusive on principles of comity." See Frymer v. Brettschneider (1994), 19 O.R. (3d) 60 at 79 (C.A.), Arbour J.A (as she then was), concurring [Frymer].

135 Muscutt, supra note 132 at 27. For a general discussion of this case, see Jeff Berryman, "Real and Substantial: The Ontario Court of Appeal's View on Service Ex Juris: Muscutt v. Courcelles" (2003) 26 Advocates' Q. 492.

13. Muscutt, supra note 132 at 27.

137 As Beth Stephens argued in the specific context of human rights litigation, "minor differences in roughly analogous systems combine to dramatically alter the legal landscape" ("Translating Filártiga," supra note 22 at 27.) See also Bell, Forum Shopping, supra note 29 at 26-38.

138 Supra note 20 at 544. For useful discussions of these jurisdictional issues, see e.g. Berryman, supra note 135, Gary D. Watson \& Frank Au, "Constitutional Limits on Service Ex Juris: Unanswered Questions From Morguard" (2000) 23 Advocates' Q. 167; John McEvoy, "After Tolofson: Wither Canadian Choice of Law" in Looking Ahead, supra note 113 at 148; Peter Kincaid, "Jensen v. Tolofson and the Revolution in Tort Choice of Law" (1995) 74 Can. Bar. Rev. 537; Janet Walker, "A Tale of Two Fora: Fresh Challenges in Defending Multijurisdictional Claims" (1996) 33 Osgoode Hall L.J. 549; J. Swan, "Choice of Forum and Choice of Law: The Implications of the New Criteria for Judicial Control" (1996) 18 Advocates' Q. 1; Symposium, "Morguard Investments Ltd. v. De Savoye" (1993) 22 Can. Bus. L.J. 2; and Ellen L. Hayes, Forum Non Conveniens in England, Australia and Japan: The Allocation of Jurisdiction in Transnational Litigation" (1992) 26 U.B.C. L. Rev. 41. In the U.S., see e.g. Craig C. Reilly, "Forum Non Conveniens: You Can Get There from Here" (Fall 1997) 24 Litigation 36. 
In the following three sections, I will look at three jurisdictional determinations: from the U.S., ${ }^{139}$ England, and Canada. These cases provide important examples of how threshold procedural decisions - particularly in the context of commercial globalization - potentially intersect with international human rights to create power-providing, "meaning-producing" acts.

\section{UNION CARBIDE}

The Union Carbide case, perhaps better than any other, demonstrates why jurisdictional determinations - fundamentally questions of procedural power - are such important, "meaning-producing" ${ }^{40}$ decisions in the context of civil litigation. As briefly discussed above ${ }^{141}$ thousands of residents of the City of Bhopal in central India suffered injury and death on the night of 2-3 December 1984. The tragedy resulted from a massive leak of the highly toxic methyl isocyanate gas - used to make Sevin and Temik pesticides - at UCC's Bhopal chemical plant (UCIL). ${ }^{142}$

13) As discussed above (supra note 45 and accompanying text), this article does not purport to provide a comprehensive review of U.S. civil human rights litigation. However, given that the Union Carbide progeny (see e.g. Bano, supra note 2) involve some of these principles, and further, given the potential relevance to the ideas discussed in this article, I will briefly discuss this issue here. In addition to general U.S. jurisdictional approaches (see e.g. the Court's approach in Union Carbide, supra note 2 and infra Part IV.B.1) a separate head of "long-arm" jurisdiction is provided for in the U.S. by the Alien Tort Claims Act, 28 U.S.C. $\$ 1350$ (1994). See also the Torture Victims Protection Act, Pub. L. No. 102256, 106 Stat. 73 (1992). The Alien Tort Claims Act, originally enacted in 1789, provides U.S. federal courts with "original jurisdiction" over "any civil action by an alien for a tort only" that is "committed in violation of the law of nations" $(\$ 1350)$. The case that opened the door for this type of modern litigation was Filártiga v. Peña-Irala, 630 F.2d 876 (2d Cir. 1980). This case and the cases that followed have been the subject of significant judicial and academic focus in the United States over the past 20 years. See e.g. Stephens, "Translating Filártiga," supra note 22; Stephens, "The Amorality of Profit," supra note 23 at ff. VI.B; and Koh, supra note 45 . For a very recent example of this type of claim, see e.g. the class action complaint filed in the United States District Court, Northern District of Illinois, Eastern Division, by Falun Gong victims of alleged human rights violations in China: Plaintiffs $A, B, C, D, E, F$, and Others, Similarly Situated, Wei Ye and Hao Wang v. Jiang Zemin and Falun Gong Control Office, A.K.A. Office 6/10, complaint available online: Justice and Accountability $<$ www.flg justice.org/cases/Jiang/Legal_Documents/Complaint_JZM.htm $>$. For a recent discussion of this case, see e.g. Clearwisdom.net, "April 16 Update on Lawsuit Against Jiang Zemin and 610 Office for Genocide" (16 April 2003), online: Justice \& Accountability <www.flgjustice.org/ cases/Jiang/Media_Reports/20030416CW.htm>. The specific legislative and constitutional traditions allowing for this type of litigation are largely unique to the United States. According to Beth Stephens' recent research, "[n]o other legal system has a comparable statute" "Translating Filártiga," supra note 22 at 32). For this reason, "[c]ivil human rights litigation generally continues to be viewed as a peculiarly U.S. phenomenon" (ibid. at 3). Stephens supports this statement by her research that "uncovered citations to Filártiga in only two cases outside the United States," both from English courts (ibid. at 3, n. 4). Stephens does, however, acknowledge that there are jurisdictions where "such claims can be brought directly, pursuant to customary international law" (ibid. at 32). For a useful discussion of these issues from a Canadian perspective, see Craig Scott, ed., Torture as Tort: Comparative Perspectives on the Development of Transnational Human Rights Litigation (Oxford and Portland: Hart Publishing, 2001), cited in Stephens, "Translating Filártiga," ibid. at 3, n. 5. 
Claims relating to the disaster were ultimately consolidated and brought by the Government of India in New York, ${ }^{143}$ the home state of UCC. In response, UCC brought a preliminary procedural challenge to the Court's jurisdiction on the basis of forum non conveniens. ${ }^{144}$

In its deliberations, the Court was guided by the forum non conveniens principles set out by the U.S. Supreme Court in Gulf Oil Corp. v. Gilbert ${ }^{145}$ and Piper. ${ }^{146}$ Essentially, as Keenan J. indicated, "Piper teaches a straightforward formulation of the doctrine of forum non conveniens. A district court is advised to determine first whether the proposed alternative forum is 'adequate' .... Then ... the district court should consider relevant public and private interest factors ... in order to determine whether dismissal is favored." 147 According to Keenan J., again relying on Piper, "a plaintiff's choice of forum" is entitled to "great deference" when the forum chosen is "the home of the plaintiff." When the plaintiff "is foreign, however, this assumption is much less reasonable ... a foreign plaintiff's choice deserves less deference." ${ }^{148}$ In sum, the Court was asked to determine which forum "will best serve the convenience of the parties and the ends of justice."149

Guided by these principles, Keenan J. reviewed the various connecting factors including the location of the accident, injury, evidence and witnesses, issues of administrability, and other public and private interests. After weighing these factors, the Court determined that the Indian Courts would be better situated to handle the claims, thereby granting UCC's motion resulting in the dismissal of the consolidated claim in the U.S. ${ }^{150}$

Subsequently, the Government of India filed suit against UCC in India in the Bhopal District Court. Independent criminal proceedings were also launched. The claims, initially for an amount of over U.S. \$3.3 billion, were ultimately settled in India for less than U.S.

143. Approximately 145 class actions were filed in various federal courts throughout the United States following the disaster. The Judicial Panel on Multidistrict Litigation consolidated these cases in the Southern District of New York by order of 6 February 1985 (see 601 F.Supp. 1035). On 29 March 1985 the Indian Government adopted the Bhopal Gas Leak Disaster (Processing of Claims) Act (1985) [Bhopal Act]. This legislation - upheld by the Supreme Court of India in Sahu v. Union of India, A.I.R. 1990 S.C. 1480 - gave the Indian Government the exclusive right to represent Indian plaintiffs in India and elsewhere in connection with the tragedy. A consolidated complaint was then filed on 28 June 1985. As of the date of the Union Carbide hearing. there were reportedly 487,000 claims filed in India pursuant to the Bhopal Act. See Union Carbide, supra note 2 at 844-45; and Bano, supra note 2 at $122-25$.

144 See Union Carbide, supra note 2.

145330 U.S. 501 (1947).

146 Supra note 132. See also A.F. Lowenfeld, International Litigation and Arbitration (St. Paul, Minn.: West Publishing, 1993) at 263-80.

147 Union Carbide, supra note 2 at 845.

148 Ibid.

149 Reilly, supra note 138 at 36.

150 In reaching this conclusion, the Court appears to have been most influenced, in its ultimate determination, not on its initial review of the relevant private and public interest and policy factors, but rather, on its concluding sovereignty-based argument that India should be permitted to resolve the case in its own courts. As Keenan J. stated, "To deprive the Indian judiciary of this opportunity to stand tall before the world and to pass judgment on behalf of its own people would be to revive a history of subservience and subjugation from which India has emerged. India and its people can and must vindicate their claims before the independent and legitimate judiciary created there since the Independence of 1947" (Union Carbide, supra note 2 at 867). 
$\$ 500$ million. ${ }^{151}$ The settlement was made pursuant to orders of the Supreme Court of India that validated the civil suit settlement, but did not ultimately end the criminal proceedings. ${ }^{152}$ This settlement amount was significantly less - "paltry" according to one commentator ${ }^{153}$ — than would be typically expected from a U.S. jury award. ${ }^{154}$ The plaintiffs "have largely felt the settlement deal to be inadequate." 155

Important to this analysis is the recognition of the disappointment of the victims and their families with respect to the resulting compensation. Given the continuous litigation efforts and international outcry that resulted from the case's dismissal in the U.S., the view that an injustice was visited upon the victims and their families - through the refusal to allow the case to proceed in the U.S. — is not particularly controversial. ${ }^{156}$ Mr. Justice V.R. Krishna Iyer of the Indian judiciary recently commented on the Bhopal disaster and its subsequent handling. In his remarks he commented that in the context of "globalization," operations from the U.S. "can pollute India" and produce "incalculable damage to Indian people."157

Perhaps equally significant, however, is the systemic recognition that this type of "incalculable damage" directly involves important international human rights. The Union Carbide case clearly raises serious concerns about whether the plaintiffs were ultimately granted, "in a suit at law," a "fair ... hearing by a competent ... tribunal."158

There is no allegation here that the Indian judicial system is not, as a general matter, competent. However, a key element of the Union Carbide case was India's own submission that questioned its ability adequately to conduct the Bhopal litigation. ${ }^{159}$ Through its submissions and expert evidence, as supported by submissions from several amicus curiae ${ }^{160}$ India identified several areas of concern with its legal system. Procedurally, India argued that its legal system was inadequate for the Bhopal litigation in a number of ways, including: a "lack of broad-based legislative activity"; "inaccessibility of legal information and legal services"; "burdensome court filing fees"; "limited innovativeness with reference to legal practice and education"; "delay and backlog"; a "lack[]" of "wherewithal ... to deal

$151 \quad$ Bano, supra note 2 at 123.

152 See Union Carbide Corp. v. Union of India, A.I.R. 1990 S.C. 273, A.I.R. 1992 S.C. 248. The criminal proceedings went forward resulting in the attachment of UCC's remaining assets in India. See Bano, supra note 2 at 123-24.

15.3 C. Scott, "Multinational Enterprises and Emergent Jurisprudence on Violations of Economic, Social and Cultural Rights" in Steiner \& Alston, supra note 31 at 1079.

154 See ibid. See also Talpis \& Kath, supra note 15 at paras. 145-46.

$155 \quad$ See ibid. at para. 146.

156 Even if a U.S. court had taken the case but applied Indian law, if the case were heard by a U.S. civil jury, there is a significant likelihood that damages would have been higher than those upon which the parties ultimately settled. See Scott, supra note 153 at 1079.

"Human Rights and the Indian Judiciary's Constitutional Jurisprudence" (Remarks, Harvard Law School Symposium, 15 April 2000) [unpublished]. Mendes and Mehmet have similarly commented that the "Bhopal tragedy is one of several twentieth-century disasters that have shown the power of the global private sector to wreak havoc on the health and safety of neighboring communities" (supra note 3 at 123). ICCPR, supra note 54, art. 14, discussed supra, Parts III.A.2, note 60, III.C, notes 85-86 and accompanying text.

(5') See further supra note 23 and accompanying text.

If(x) The amicus curiae included the Citizens Commission on Bhopal, the National Council of Churches, and the United Church of Christ Commission for Racial Justice, et al. See Union Carbide, supra note 2 at 847, n. 4. 
effectively and expeditiously" with the case; a bar that "lack[s] specialization, practical investigative techniques and coordination into partnerships" that "limit[s]" its "ability to handle the ... litigation"; "pre-trial discovery" that is "inadequate"; a "lack of devices for third-party impleader or for organizing complex cases"; a lack of "class action procedure"; an "unavailability of juries or contingency fee arrangements"; and the fact that "a judgment rendered by an Indian court cannot be enforced in the United States without resort to further extensive litigation." 161 India identified equally problematic substantive hurdles, including: a tort law system that was "not sufficiently developed to accommodate the Bhopal claims"; "little reported case law in the tort field to serve as precedent"; and "no tort law relating to disputes arising out of complex product or design liability."

In sum, according to India's own submissions, these procedural and substantive "deficiencies" would "thwart the victims' quest" for "justice." 163 In response to all of the concerns raised by the Indian Government, defense experts argued that India's legal system was up to the task of handling the litigation. ${ }^{164}$ In my view, however, as set out above, ${ }^{165}$ notwithstanding competing expert evidence, there clearly were serious issues as to India's ability - in this case and on its own admission - to provide the plaintiffs with access to meaningful, "competent" justice.

While not at issue on the procedural motion before the Court, other basic international human rights discussed above were also clearly affected, ${ }^{166}$ including the right against arbitrary deprivation of property and rights to adequate protections of the home, working conditions, standards of living, and environmental and industrial hygiene. Whether claims for violations of these rights would have succeeded is an open question. However, given the various threshold jurisdictional refusals, ${ }^{167}$ none of these substantive rights was litigated. ${ }^{168}$

\section{Ibid. at 847-52.}

Ibid. at 849 .

Ibid. at 847 .

Ibid. at 847-52.

See supra notes 159-63 and accompanying text.

See generally supra Parts III.A and C.

See Union Carbide, supra note 2; and Bano, supra note 2.

For example, the claims in Bano alleged essentially 15 violations of U.S. and international law including allegations based on: criminal activity; racial discrimination; cruel, inhumane and degrading treatment; violations of the right to life, health and security of the person; violations of international environmental law; gross violations of human rights; civil contempt; fraud; negligence; public and private nuisance; trespass; and other issues involving strict liability, medical monitoring and other equitable relief. In terms of the specific alleged human rights violations, the class action complaint set out the following allegations:

Union Carbide's conduct ... amounted to a consistent pattern of gross violations of recognized human rights insofar as Union Carbide operated and maintained a plant in Bhopal, India which continuously posed a grave risk of death and/or serious physical injury to the surrounding population; that each incident manifesting its depraved indifference to the grave risks posed to that population amounted to a violation of recognized human rights to life, health and security of the person; that there were several, repeated incidents of such toxic leakage which injured workers and hundreds of nearby residents; and that Union Carbide on each occasion ignored the grave risk of death and serious physical injury posed by its facility in Bhopal. In addition, Union Carbide's conduct after the Bhopal gas disaster demonstrates a consistent pattern of gross violations of recognized human rights because of its failure to provide adequate information about MIC [gas] to those treating the victims, including, but not limited to, Union Carbide's failure to disclose any information on the medical consequences, toxicity or ultrahazardous character of MIC prior to and after the occurrence of the Disaster. Further, Union Carbide's purposeful absconding from the 
In terms of the "correctness" of the Union Carbide decision, there is no doubt that the argument could be made (as it was, and as the Court accepted) that India had a "significant relationship" with the matters at issue in the litigation. Further, it can be seen that India also had a clear "interest" in the litigation. On this literal reading, there were reasonable bases for the decision. However, the arguments against the U.S. Court taking jurisdiction might have been stronger had India, as representative plaintiff, not been a party to the litigation. In its submissions, according to the reasons of Keenan J., India "argued that the courts of India are not up to the task of conducting the Bhopal litigation." ${ }^{69}$ Notwithstanding this assertion, the Court rejected India's stated interest and concern, finding instead, on India's behalf, that its courts "have the proven capacity to mete out fair and equal justice." 170

As can be seen through the Bhopal experience, domestic procedural determinations clearly have direct and determining implications for the potential acknowledgment and protection of fundamental human rights. As Mr. Justice Krishna lyer argued, courts therefore "need to be aware of more than just compensation." "71 Had the Court in Union Carbide been willing to take a more commercially globalized, less sovereignty-based ${ }^{172}$ view of the matter, and recognized that, by taking the benefit of its Indian location, UCC should also take responsibility for its local UCIL actions and the resulting impacts on the international human rights of local citizens, the result might have been different. The Court might have been more persuaded by the argument that the Federal Court in the U.S., and not the Bhopal District Court, particularly given the potential procedural and substantive hurdles raised in the case, ${ }^{173}$ was the more appropriate place to litigate the matter in order to secure adequate and meaningful justice. ${ }^{174}$

criminal jurisdiction of India's courts also represents a continuous, ongoing violation of the Plaintiffs' right to a remedy at law in violation of customary international law, as embodied in Article 8 of the Universal Declaration of Human Rights which states that "[e]veryone has the right to an effective remedy by the competent national tribunal for acts violating the fundamental rights guaranteed to him by constitution or by law" and Article 2(3) of the International Covenant on Civil and Political Rights ... Union Carbide's conduct as described herein was unlawful, reckless, malicious and reprehensible and was in deliberate, conscious and wanton disregard of the lives, rights and safety of the residents of Bhopal.

Bano et al. v. Union Carbide Corporation and Warren Anderson, Amended Class Action Complaint, 99 Civ. 11329 (JFK) (S.D.N.Y. 1999) at para. 63.

Union Carbide, supra note 2 at 867. See also supra notes 159-63 and accompanying text.

Union Carbide, ibid. at 867.

Iyer, supra note 157

See infra notes 174-76 and accompanying text (discussing Hartford Fire Insurance Co. v. California, 509 U.S. 764 (1993) [Hartford Fire]).

See supra notes 161-62.

Judge Keenan's approach in Union Carbide can be contrasted with the United States Supreme Court's approach in Hartford Fire, supra note 172. In that case - admittedly under different regulatory circumstances - the Court considered the extraterritorial reach of the Sherman Act, 15 U.S.C. § 1. The case involved allegations of conspiracy by 19 states and a number of private plaintiffs that were brought in the U.S. against several London reinsurance companies. The plaintiffs alleged that the English companies conspired to coerce primary U.S. insurers to change the nature and coverage of their primary policies with respect to certain commercial general liability and environmental coverage in the U.S., specifically in California. The activity in question took place mainly in the U.K. The defendants were British corporations and British subjects with their principal place of business or residence outside of the U.S. It was also established that the U.K. had a comprehensive regulatory framework governing its reinsurance industry. The defendants pleaded that their actions did not offend against that U.K. framework. Notwithstanding these significant U.K. connections - together with an amicus curice brief filed by the U.K. Government objecting to the extraterritorial application of the Sherman Act, the 
A similar view has been supported by Kanishka Jayasuriya who, when discussing the jurisdictional significance of the Hartford Fire ${ }^{175}$ decision, commented that:

$[T]$ he territorial model of sovereignty is giving way to more flexible notions of jurisdiction based on effects rather than place of conduct. The debate over the consistency of the decision with the notions of jurisdiction in international law is relevant in that it points to the elasticity of the notion of sovereignty in the face of the changing structure of global economic relations. ${ }^{176}$

On a more expansive, globalized view of jurisdiction — based on a more "elastic[]" view of sovereignty - the Indian nationals, through the Government of India, should, in my view, have been afforded access to the litigation benefits that would have accompanied access to the home state of UCC. It was, however, a powerful tool of civil procedure - a threshold jurisdictional determination - that denied them that access and, in my view, adequate justice.

\section{2. $L U B B E$}

In $L u b b e,{ }^{177}$ the House of Lords was more recently faced with tragic claims involving over 3,000 plaintiffs from South Africa - mostly "black and of modest means" 178 - seeking to sue the English parent company, Cape plc, for significant asbestos related injuries and deaths.

argument from which was not successful (see Symeonides et al., supra note 130 at 558) - a majority of the United States Supreme Court held that permitting these claims to be brought in a U.S. District Court under these circumstances did not necessarily offend against traditional conceptions of international comity (Hartford Fire at 799, Souter J.). The Court was obviously concerned about the practicalities of regulating insurance activities and anti-competitive activities that potentially involved U.S. nationals and industries, regardless of where the activities originated or took place. In so doing, it relied on an effects-based analysis of extraterritoriality, ignoring recent (more formal) comity-based U.S. precedents. The majority made no mention of its earlier holdings reiterating the presumption against extraterritoriality, including: EEOC. v. Arabian American Oil Co., 499 U.S. 244 (1991); Smith v. United States, 507 U.S. 197 (1993); and Sale v. Haitian Centers Council, 509 U.S. 155 (1993). For a discussion of the Court's lack of reference to these earlier holdings, see Symeonides et al., supra note 130 at 558. Justice Scalia, in dissent, relied on the Restatement (Third) of Foreign Relations Law $\$ 403$ (1987) in his opinion that "[r]arely" would the principles of international law "point more clearly against application of United States law"(Hartford Fire at 819).

A determining factor in both the Union Carbide and Hartford Fire cases was obviously the location of the alleged damage. However, if a more expanded, global view of damage had been adopted, would the location of the damage then have been so clear? Take, for example, the Union Carbide case. What about other damaged interests, including those of U.S. environmental regulators and labour organizations, U.S. trade interests and foreign relations policies, other developing nations that may be forced to keep regulatory policies at a minimum in order to retain foreign corporate facilities, U.S. employees whose jobs may be lost as a result of "corporate flight" to jurisdictions with "cheaper" labour, regulatory and damages regimes, etc.? Clearly not all of these individuals and groups were parties to the litigation. But, even without acknowledging the human rights claims that were potentially at issue, can it be said that the damages involved in the case were limited to India, such that the U.S. did not have a viable interest in adjudicating the matter? For a useful consideration of some of these competing interests involved in the Union Carbide case, see Paul, "Isolation," supra note 130 at 177, in which Joel Paul described the decision as "formalistic deference to sovereign equality." See also Joel Paul, "Comity in International Law" (1991) 32 Harv. Int'l L.J. 1 at 62-63, 70-71.

Supra note 174.

"Globalization, Law, and the Transformation of Sovereignty: The Emergence of Global Regulatory Governance" (1999) 6 Ind. J. Global Legal Stud. 425 at 436-37 [citations omitted]

Supra note 132.

Ibid. at para. 2, Bingham L.J. 
At issue were allegations against the defendant "as parent company which, knowing ... that exposure to asbestos was gravely injurious to health, failed to take proper steps to ensure that proper working practices were followed and proper safety precautions observed ... by its overseas subsidiaries." 179

The case before the House of Lords was a jurisdictional appeal primarily based on principles of forum non conveniens. The defendant had responded to the plaintiffs' claim by moving to stay the proceedings against it in the U.K. The primary arguments in favour of the plaintiffs' position on the motion included that:

legal aid in South Africa had been withdrawn for personal injury claims, that there was no reasonable likelihood of any lawyer or group of lawyers being able or willing to fund proceedings of this weight and complexity under contingency fee arrangements ... and that there was no other available source of funding open to the plaintiffs. ${ }^{180}$

As a result, in addition to forum non conveniens principles set out in Spiliada, ${ }^{181}$ the plaintiffs argued that their rights to a fair trial as guaranteed by section 6 of the $E C H R^{182}$ were at stake. $^{183}$

The Court, in reviewing the competing positions, applied the governing principles set out in Spiliada ${ }^{184}$ and Connelly. ${ }^{185}$ According to Spiliada, for forum non conveniens determinations, "a stay will only be granted ... where the court is satisfied that there is some other available forum, having competent jurisdiction, which is the appropriate forum for the trial of the action, i.e., in which the case may be tried more suitably for the interests of all the parties and the ends of justice." 186

This test essentially requires two considerations. First, "[i]n applying this principle the court's first task is to consider whether the defendant ... is able to discharge the burden ... not just to show that England is not the natural or appropriate forum ... but to establish that there is another available forum which is clearly or distinctly more appropriate." 187 If the court concludes at this stage that "there is no other available forum which is clearly more appropriate," that is "likely to be the end of the matter." 188

Supra note 132.

Supra note 68.

Lubbe, supra note 132 at para. 31 . Lord Justice Bingham specifically contemplated the provisions of $E C H R$, art. 6 for a right to a fair trial in his earlier views, sitting on the Court of Appeal, in that Court's decision in Connelly v. RTZ Corporation plc, [1997] 4 All E.R. 355. The ECHR, art. 6, as the Court noted in Connelly, closely reflects the provisions of the ICCPR, art. 14(1). For the House of Lords decision in Connelly, see [1998] A.C. 854 [Connelly cited to A.C. unless otherwise indicated]. For useful discussions on this point, see Bell, Forum Shopping, supra note 29 at 155; and Bell, "Human Rights and Transnational Litigation," supra note 85 at 126-27. 
Second, however, "if the court concludes at that stage that there is some other available forum which prima facie is more appropriate ... it will ordinarily grant a stay unless the plaintiff can show that there are circumstances by reason of which justice requires that a stay should nevertheless not be granted." 189 At this second stage of the analysis, the court will "concentrate its attention not only on factors connecting the proceedings with the foreign or the English forum ... but on whether the plaintiff will obtain justice in the foreign jurisdiction." 190 This step will be satisfied "only if the plaintiff can establish that substantial justice will not be done in the appropriate forum."

Lubbe was essentially decided at the second step of the Spiliada test. As Bingham L.J. argued in his earlier Court of Appeal decision in Connelly, ${ }^{192}$ proceedings should not be stayed if, as Bell has paraphrased, "that would have the practical effect of preventing a plaintiff from pursuing his or her rights anywhere." ${ }^{193}$ Although the Court ultimately found that $E C H R$ article 6 added nothing to the Court's Spiliada-based reasoning, ${ }^{194}$ it is clear, as in the Union Carbide case, that human rights based issues were implicated. ${ }^{195}$ In fact, Andrew Bell has argued that the " "justice' exception" to the Spiliada doctrine "provides the first and perhaps most obvious context in which human rights considerations may fall to be considered in the context of the practical operation of the principles of private international law." ${ }^{196}$ In

189) Ibid.

19\% Ibid.

191 Ibid. The Spiliada approach was usefully summarized, favourably, by Sopinka J. in Amchem:

In Spiliada ... the House of Lords restated the rule and elaborated on its application. In particular, the court dealt with its application in what it considered two different circumstances. In the "as of right" cases in which the defendant was served in the jurisdiction, the burden of proof that a stay should be granted was on the defendant who was required to show that there is another forum which is clearly more appropriate for the trial of the action. This so-called "natural forum" is the one with which the action has the most real and substantial connection. If this first condition is established, a stay will be granted unless the plaintiff establishes special circumstances by reason of which justice requires that the trial take place in England. Mere loss of a juridical advantage will not amount to an injustice if the court is satisfied that substantial justice will be done in the appropriate forum. In cases in which service is effected ex juris, the burden is on the plaintiff throughout and is the obverse of that applicable in cases as of right; that is, the plaintiff must show that England is clearly the appropriate forum. Lord Goff provided some guidance with respect to the relevant factors that determine the appropriate forum. While not intending to provide an exhaustive list, His Lordship referred to the principal factors in his reasons at p. 478: "So it is for connecting factors in this sense that the court must first look; and these will include not only factors affecting convenience or expense (such as availability of witnesses), but also other factors such as the law governing the relevant transaction ... and the places where the parties respectively reside or carry on business."

Amchem, supra note 1 at $339-40$.

Connelly, supra note 183, cited in Bell, Forum Shopping, supra note 29 at 155 . For a related discussion of the potential impact of art. 6 of the ECHR on anti-suit injunctions, see ibid. at 205-206. Bell, ibid. at 155 .

194 Lubbe, supra note 132 at para. 31. In Lubbe, there was adequate room in the Spiliada exception "circumstances by reason of which justice requires" - to refuse the stay. See Spiliada, supra note 132 at 478 , Goff L.J.; and infra at note 215 and accompanying text.

It is important to acknowledge that the Court in Lubbe expressly rejected a jurisdictional determination based on "questions of judicial amour propre and political interest or responsibility." Rather, the Court preferred a determination based on its Spiliada test. In concurring reasons, Lord Hope of Craighead elaborated on this preference, specifically distinguishing the House of Lords' approach from that followed by "judges in the United States who would decide issues as to where a case ought to be tried on broad grounds of public policy: see ... Union Carbide and Piper" (Lubbe, supra note 132 at paras. $32,49-52$ )

1\% "Human Rights and Transnational Litigation," supra note 85 at 119. 
Lubbe, however, unlike in Union Carbide, the Court ultimately allowed the appeal and lifted the stay of the U.K. proceedings.

On the merits of Lubbe, the allegations against Cape plc - in substance - were closely analogous to ICESCR article 7 rights to "safe and healthy working conditions." ${ }^{197}$ On the threshold procedural motion, again like Union Carbide, access to meaningful justice, this time in the form of access to funding, was at issue. As Bell has further argued, access to justice considerations in jurisdictional determinations "accord[] with the basic right enshrined in article 14(1) of the ICCPR ... in the determination of civil rights and obligations." 198 Again, in Lubbe, we see the powerful and important intersection between globalization and international human rights on the one hand and domestic procedural determinations on the other.

\section{RECHERCHES INTERNATIONALES}

A third case to consider the issue of access to the due process of law in the context of a preliminary civil procedural determination under the lens of globalization is the Quebec Superior Court's decision in Recherches Internationales. ${ }^{199}$ In that case, the dam of a gold mine effluent treatment plant ruptured in the South American country of Guyana. The plant was owned by Omai Gold Mines Limited (Omai), a Guyanan corporation. Approximately 2.3 billion litres of liquid containing cyanide, heavy metals, and other pollutants spilled into several rivers, one of which was Guyana's main Essequibo waterway.

There were approximately 23,000 Guyanese victims of the spill. They brought a class action in Quebec against Cambior Inc. (Cambior), a Quebec corporation and 65 percent owner of Omai. ${ }^{200}$ The spill was described as "[o]ne of the worst environmental catastrophes in gold mining history."201

In determining whether Quebec was the appropriate forum for the litigation in the face of a forum non conveniens challenge, the Court acknowledged that the "well-established common law doctrine of forum non conveniens was incorporated into the Quebec Civil Code under Article 3135." ${ }^{202}$ When interpreting Article 3135, the Court further indicated that "common law precedents ... serve as a useful guide in interpreting Article 3135."203 The

ICESCR, supra note 55, art. 7(b). See also supra note 63.

"Human Rights and Transnational Litigation," supra note 85 at 121. Further, see Lord Goff's comments in Spiliada in which he specifically acknowledged that the factor of whether a plaintiff will "obtain justice in the foreign jurisdiction" - established "objectively by cogent evidence" — is a factor that will require judicial consideration beyond the typical connecting factors (see Spiliada, supra note 132 at 478). See also The Abidin Daver, [1984] A.C. 398 at 411 (H.L.), Diplock L.J. For a useful commentary on these cases, see Bell, ibid. at 116-27.

Supra note 116.

Ibid. at para. 2.

Ibid. at para. 1 .

Ibid. at para. 28. As the Court indicated, Article 3135 provides that: "Even though a Québec authority has jurisdiction to hear a dispute, it may exceptionally and on an application by a party, decline jurisdiction if it considers that the authorities of another country are in a better position to decide." (Ibid.)

Ibid. at para. 31. 
Court then looked "in particular" to the Amchem case. ${ }^{204}$ In Amchem, after favourably reviewing the English authorities including Spiliada, Sopinka J. provided that the test in Canada, although guided by those English authorities, was to be essentially a one-step question: "is there a more appropriate jurisdiction based on the relevant factors[?]"205

When evaluating whether to allow the class action to proceed in Quebec, the Court considered the important issue of whether the plaintiffs would have access to meaningful justice in Guyana ${ }^{206}$ Competing pictures of Guyana's legal capacities were presented to the Court. Citing several sources including the 1996 U.S. State Department Country Report on Human Rights and Prime Minister Janet Jagan, the plaintiffs' expert argued at the time of the hearing that the administration of law in Guyana had "reached a state of collapse," that Guyana's judiciary was "corrupt" ${ }^{207}$ and demoralized, and that the "inefficiency of the judicial system is so great as to undermine due process." ${ }^{208}$ The expert for the defendant Cambior disagreed with these statements, testifying to the adequacy of Guyana's legal system. ${ }^{209}$

In its decision, the Court preferred the evidence of Cambior's experts and, therefore, granted Cambior's motion. Significant to this determination was the Court's assessment of the credibility of the competing expert testimony. ${ }^{210}$ Also significant was the Court's determination that based on this testimony, "justice would be rendered in Guyana." 211 However, regardless of the Court's ultimate conclusion, its consideration of access to justice

Supra note 1.

201 Ibid. at 344. Justice Sopinka, unlike the Court in Spiliada, did not expressly adopt a second "justice exception" step in Amchem. However, the Amchem test, which includes "loss of juridical advantage" as being "weighed with the other factors," (ibid. at 343 ) has been interpreted to include this principle. See e.g. Recherches Internationales: "the mere loss of a judicial [sic] advantage to the plaintiff will not amount to an injustice if the Court is satisfied that substantial justice will be done in the appropriate forum" (supra note 116 at para. 35). With this consideration in mind, the Court in Recherches Internationales expressly looked at the issue of the "interests of justice" as a separate factor in its delibertaion (see $i b i d$. at paras. 82-99).

This understanding of Amchem is further supported in the formulation of the Amchem test adopted by Arbour J.A., as she then was, concurring, in Frymer: "In all cases, the test is whether there clearly is a more appropriate jurisdiction than the domestic forum chosen by the plaintiff in which the case should be tried. The choice of appropriate forum is designed to ensure that the action is tried in the jurisdiction that has the closest connection with the action and the parties. All factors pertinent to making this determination must be considered" (Frymer, supra note 134 at 79 [emphasis added]). Further, Castel and Walker, when discussing Amchem, provide that: "Today in common law Canada, in all cases involving one or more legally relevant foreign elements, the task of the court is to apply principles designed to identify the most appropriate or appropriate forum for the litigation based on factors which connect the litigation and the parties to the competing fora.' In other words, is there an alternative forum that is clearly more convenient for the pursuit of the action and for securing the ends of justice than the forum chosen by the plaintiff?" (supra note 106 at 13.5 [citations omitted, emphasis added]). See also Markus Koehnen, "Reasonable Expectations and a Principled Approach to Forum Shopping" (1997) 19 Advocates' Q. 310 at 319-320.

This consideration was raised - in the context of the Court's discretionary forum non conveniens deliberation - when comparing the legal systems of Guyana and Quebec in order "to determine whether the remedy sought by the plaintiffs is available in the foreign jurisdiction" (Recherches Internationales, supra note 116 at para. 98).

Ibid.

Ibid. at paras. 88-97.

Ibid. at para. 92.

Ibid. at para. 97. 
in the foreign jurisdiction again, like in Lubbe, demonstrates the critical importance of this fundamental right in the context of threshold domestic civil procedural determinations.

\section{What Justice REQuiRes}

Union Carbide, Lubbe, and Recherches Internationales involve cases from the U.S., England and Canada. The tests, however, to determine whether to take jurisdiction are similar between these three common law countries. As Sopinka J. commented in Amchem, after reviewing the Spiliada and Piper decisions, together with authorities from Australian and New Zealand, "212 "the law in common law jurisdictions is, as observed by Lord Goff in Spiliada, remarkably uniform. While there are differences in the language used, each jurisdiction applies principles designed to identify the most appropriate forum for the litigation based on factors which connect the litigation and the parties to the competing fora." 213

As noted above, ${ }^{214}$ one of the key elements of the Spiliada test is the "justice exception." 215 It is this consideration, in my view, which provides the Court with the appropriate tool to take seriously the effects of modern commercial globalization when making critical jurisdictionbased determinations that will fundamentally determine the outcome, or even the viability, of a lawsuit potentially involving international human rights. Regardless of which test is applied - Piper, Spiliada or Amchem - the Court must ultimately look at the question of "what justice requires" in a given context in order to balance appropriately the competing factors in a given jurisdictional debate.

To make this argument, I am not advocating legislative reform along the lines of the Alien Tort Claims Act. ${ }^{216} \mathrm{I}$ am also not making a universal jurisdiction argument based on customary international human rights law, although certainly such an argument would provide for fruitful discussion. ${ }^{217}$ Further, I am not advocating to change the tests, or to make identical these three "remarkably uniform" 18 tests. Instead, what I am arguing is simply that, when applying a given jurisdictional test, courts need to take seriously the question of "what justice requires" in the modern context of commercial globalization. This notion of "justice" must be viewed expansively to include the kinds of international human rights considerations that were accepted by the House of Lords in Lubbe. The balancing principles provided for in Piper, Spiliada, or Amchem, combined with an expansive consideration of what justice requires - when considering the relevant public and private interest factors in Piper, at the second step in Spiliada, or as part of the one-step balancing approach in Amchem - will allow for appropriate common law jurisdictional determinations to be made without

See Amchem, supra note 1 at $337-46$.

Ibid. at 346. This point has been made by Bell, who, citing a number of decisions including Amchem, recently commented that "[t]he Spiliada doctrine has been adopted by most Commonwealth counties" ("Human Rights and Transnational Litigation," supra note 85 at 118 [citation omitted]). Supra notes $189-91$ and accompanying text.

My thinking on this point - including the use of the phrase "justice exception" - has been influenced by Andrew Bell (see "Human Rights and Transnational Litigation," supra note 85 at 119).

Supra note 139.

For a useful discussion of universal jurisdiction in the context of human rights litigation, see Stephens, "Translating Filártiga," supra note 22 at 39-53.

Amchem, supra note 1 at 346. 
legislative or significant judicial reform. ${ }^{219}$ Further, to facilitate this approach, a modern, non"parochial" sensibility of comity will need to be applied that includes due consideration for modern pressures, "effects," 220 and realities of economic globalization. ${ }^{221}$

Take, for example, the Union Carbide case. In my view, if this expansive jurisdictional approach had been adopted by Keenan J., he could have applied the Piper analysis to the facts of that case and reached the opposite result, thereby allowing the action to proceed in the U.S. Further, this effects-based justice argument should prevail, notwithstanding potential objections based on the formal corporate structure of UCC and its UCIL Indian operations. Of significant importance would have been the express consideration that commercial globalization - in that case manifested most clearly in UCIL's operations in India and the resulting damage to the Indian people and environment - has potentially violated the rights of foreign nationals abroad. Given that UCC, through UCIL, took the benefit of its operations in India, it should also have been subject to appropriate responsibilities. If the Court were persuaded that the foreign judicial system could provide adequate justice, then the matter could be stayed; for, as argued above, ${ }^{222}$ it is difficult to accept the Court's finding in Union Carbide on this point. To do so, the Court would need to take seriously the question of what justice requires, specifically balancing the demands of modern commercial globalization, the resulting potential violations of international human rights, and whether those rights truly could be adequately protected by the foreign judicial system.

I anticipate two challenges to this argument. First, calling for an expansive notion of a justice consideration will open the floodgates to "forum shopping," where a "party seeks out a jurisdiction simply to gain a juridical advantage rather than by reason of a real and substantial connection of the case to the jurisdiction." ${ }^{223}$ As the argument goes, an expansive justice consideration that takes seriously the impact of current forces of commercial globalization will essentially encourage foreign litigants to seek out courts that have plaintifffriendly jurisdiction policies and damage awards.

This objection raises valid concerns. However, given the safeguards built into these common law balancing approaches, these considerations can be dealt with through the tools

219) The argument that I am advancing in this article fits within any of the current formulations of the tests However, notwithstanding Sopinka J.'s assessment that the three common law tests are "remarkably uniform," the requirement of an express, two-step test - specifically requiring judges to consider justice as a separate factor - may in fact have a potential impact on the way that judges think about the tests, and the way that parties present their cases. Rather than including justice as one of many factors to be balanced, for example, in an Amchem-type analysis, the Spiliada approach forces all involved specifically to address the justice issue head on. While each test contemplates the issue, form may have an impact on substance in this circumstance. However, whether the Amchem test should be split in a similar fashion to Spiliada is a question for a different project. I am grateful to Ian Smith for raising this argument.

2211 See Jayasuriya, supra note 176 at 436-37.

221 For an argument similarly contemplating a liberalized forum non conveniens approach, see Kinley, supra note 82 at $43-44$.

222 Supra notes 163-65 and accompanying text.

22.3 Amchem, supra note 1 at 344. For a useful discussion on forum shopping, see Koehnen, supra note 205 For a U.S. perspective on forum shopping, see Gita F. Rothschild, "How to Have Your Cake and Eat It" (Dec. 1998 - Jan. 1999) 36 Int'l Comm. Lit. 16. 
already in place in Piper, Spiliada or Amchem-type analyses. ${ }^{224}$ The justice consideration remains an exception, or at least only one significant factor in the analysis. What I am arguing here simply advocates for an expansive, modern view of that exception that takes seriously the impacts of commercial globalization on international human rights in cases like Union Carbide.

A second challenge that I anticipate to this argument is the complaint that an expansive notion of jurisdiction will encourage American-style litigation outside of the U.S. As Stephens has commented, "it seems noncontroversial to conclude that the United States is among the countries with the highest rate of recourse to the courts to resolve disputes."225 Further, not only is litigation prevalent in the U.S., the available monetary damages, including punitive damages, are high. Again, as Stephens has pointed out, "[f]ew nations award punitive damages, and none on the scale of the United States.... Comparative studies of damage awards find ... that U.S. awards are much higher than those in any other country.".226

While on first blush there may be some merit to this point, I do not see it as a fundamental challenge to my argument. First, I am not advocating legislative reform along the lines of the Alien Tort Claims Act. ${ }^{227}$ Second, as a practical matter, modern litigation in other Western countries - like Canada - has been becoming more "American" for a number of years, not as a result of jurisdictional determinations, but largely because of our modern, Americanstyle economies. And regardless of whether we think this is a good thing, the reality is that, if we are going to push for expansive trade and commerce principles that expand the reach and depth of commercial globalization, then we need to accept the responsibilities that go with those distributional policy decisions. To the extent that the fruit of our domestic economic policy choices results in serious violations of international human rights around the world, our courts need to be available as sources of remedies when the perpetrators of those rights abuses have appropriate contacts with our domestic courts. Our interpretations of principles of comity and "real and substantial" connection need to make room for this sensibility. ${ }^{228}$

See e.g. ibid. See also Swan, supra note 138 at 14: "The Supreme Court in both Amchem and Tolofson ... is strongly opposed to forum shopping" [citation omitted]. See also ibid. at 3.

Stephens, "Translating Filártiga," supra note 22 at 24.

Ibid. at 30-31.

Supra note 139.
On a lighter note, the argument can now be made that civil procedure and "human" rights cross paths not only on the global stage, but also now on the extraterrestrial stage. In Joly v. Pelletier, [1999] O.J. No. 1728 (Sup. Ct.) (QL), Epstein J. was faced with procedural motions in the context of Mr. Joly's "firm assertion that he is not a human being; rather a martian" (ibid. at para. 2). Specifically, Joly who had brought several claims against numerous defendants including "doctors, medical facilities..., the Central Intelligence Agency, President Clinton and the Honourable Anne McClellann [sic]" asserted that the defendants conspired "to eliminate him and have otherwise taken various steps [including 'the falsification of his D.N.A. test results...'] to interfere with his ability to establish himself and live freely as a martian" (ibid. at paras. 2-3, 8). Justice Epstein granted the defendants' motions to dismiss the actions on two grounds. He found that the claims were "frivolous and vexatious and constitute an abuse of the process of this Court" (ibid. at para. 11). More interestingly, however, given Joly's assertion that he was not a person, but rather a martian, Epstein J. found that he was not a "person" for purposes of the Ontario Rules of Civil Procedure, r. 1.03, or the Ontario Interpretation Act, R.S.O. 1990, c. I.11, s. 29(1). As he stated, "The entire basis of Mr. Joly's actions is that he is a martian, not a human being. There is certainly no suggestion that he is a corporation. I conclude, 


\section{OTHER Procedures}

In addition to jurisdictional determinations, there are other procedural tools that exemplify how civil procedure potentially implicates important issues of international human rights in the context of commercial globalization. Several of those tools are discussed briefly below.

\section{Class ACTIONS}

Class actions are increasingly going to be a procedural tool engaged at the juncture of commercial globalization and international human rights. As Sopinka J. remarked in Amchem, in this era involving an "increase of free trade and the rapid growth of multinational corporations," plaintiffs will increasingly involve "a large class residing in different jurisdictions." 229 More recently, according to Cumming J., "the internationalisation of class members will also become more prevalent with complex litigation.... The principle of comity will gain increasing importance as the courts of several jurisdictions must deal with parallel litigation that impacts upon the citizenry across those several jurisdictions." 230

Union Carbide, ${ }^{231}$ Lubbe, $^{232}$ and Recherches Internationales ${ }^{233}$ all provide examples of class or group actions involving victims almost exclusively residing in one jurisdiction. However, as contemplated by the statements of Sopinka J. and Cumming J., ${ }^{234}$ classes will more and more involve parties from more than one jurisdiction. ${ }^{235}$ This is particularly likely in an era of "head spinning" "236 commercial globalization in which mass tort cases involving goods and services distributed in multiple jurisdictions are increasingly involved. ${ }^{237}$ As Janet Walker has recently argued,

[i]ncreasingly, national courts and dispute resolution are coming to be used to vindicate the collective rights of persons ... [G]roups are now turning to the courts as arbiters of their rights where these rights have been

therefore, that Mr. Joly, on his pleading as drafted, has no status before the Court" (ibid. at para. 11). See supra note 129 and surrounding text.

Wilson v. Servier Canada Inc. (2002), 26 C.P.C. (5th) 194 (Sup. Ct.) at para. 29 [Wilson]. See also related litigation: Wilson v. Servier Canada Inc. (2000), 50 O.R. (3d) 219 (Sup. Ct.), leave to appeal to Div. Ct. refused (2000), 52 O.R. (3d) 20 (Sup. Ct.) leave to appeal to S.C.C. refused [2001] S.C.C. File No. 28380. See further Mondor v. Fisherman (2002), 26 B.L.R. (3d) 281 (Ont. Sup. Ct.) [Mondor]; and Paraschos, supra note 133, cited in Mondor, ibid.

Supra note 2.

Supra note 132.

Supra note 116.

Supra notes 229-30 and accompanying text.

See e.g. Paraschos, supra note 133, where securities fraud allegations were brought by a class of victims residing in both the United States and Canada. For a useful discussion of this case in the context of international dispute resolution, see Walker, supra note 113 at 107. See also Kent \& Coe, supra note 131 at Part III.

Jackson, supra note 36 at 1.

For a useful discussion of the use of international class actions, see Richard O. Faulk, "Armageddon through Aggregation? The Use and Abuse of Class Actions in International Dispute Resolution" in Charles E.F. Rickett \& Thomas G.W. Telfer, eds., International Perspectives on Consumers 'Access to Justice (Cambridge: Cambridge University Press, 2003) at 330-55. See also Debra L. Bassett, "U.S. Class Actions Go Global: Transnational Class Actions and Personal Jurisdiction" (2003) 72 Fordham L. Rev. 41 . 
infringed upon or impaired by governments or businesses ... [I]t is increasingly the case that the multi-state, multi-province or multinational nature of consumer markets gives rise to similarly constituted class actions. ${ }^{238}$

Further, to the extent that government policy and trade regimes continue to provide unsatisfactory protections against the negative impacts of economic globalization, ${ }^{239} \mathrm{NGOs}$ and other public interest advocates may see international class actions as viable opportunities for regulating negative international economic behaviour. As Walker has further argued,

to the extent that multi-jurisdictional classes come to be a viable option for the vindication of collective or group rights, national courts will increasingly become the forum for the debate and resolution of issues that would once have been addressed in political or diplomatic fora ... [C]lass actions relating to international disputes in national courts can generate pressure to change procedural and substantive national law in ways that once might have been left to legislators or members of the executive. ${ }^{240}$

On the cautious side, Richard Faulk has warned that the use of class actions internationally needs to be carefully scrutinized in the context of influencing social policy. According to Faulk:

[t]he use of American or, for that matter, any other nation's collective liability devices to resolve claims of non-resident foreign litigants represents a major intrusion into the internal social policies and cultures of sovereign states. Although "globalism" may be useful as a commercial cliché, its intrusion into jurisprudence is disturbing, especially when procedural devices that are not yet recognised internationally are used to resolve claims arising from conduct that occurs beyond the forum state's borders. Accordingly, it is prudent that proposals seeking to expand the use of the class action device internationally, or that would allow the international enforcement of class action judgments by treaty, should be evaluated cautiously. ${ }^{241}$

Whether one is bearish or bullish on this point, it seems clear that class actions are becoming important procedural tools for dealing with claims involving international contacts - including international human rights claims - in the context of commercial globalization. ${ }^{242}$

\section{RECOGNITION OF FOREIGN JUDGMENTS}

Recognition of foreign judgments is another aspect of civil procedure that will become increasingly relevant to this analysis. As Berman has recently argued, "I see jurisdiction and recognition of judgments as fruitful sites for thinking about the relationship between the 'local,' the 'national,' and the 'global' and for mapping the evolving ways in which people construct identity by reference to places and/or communities." ${ }^{243}$ As another recent comment suggested:

Supra note 113 at $106-107$.

For a recent discussion identifying some shortcomings of various international trade regimes, see e.g. Mendez \& Mehmet, supra note 3 at 72-73.

Supra note 113 at 107-109. See also Boyd, supra note 45 at 1208-12.

Supra note 237 at 331.

For a recent general discussion on the use of class actions from a Canadian perspective, see J. Melnitzer, "The Dog-Eat-Dog World of Class Actions" Lexpert (July/August 2003) 50. See also K. Makin "ClassAction Suits Explode Into 'National Phenomenon'” The Globe and Mail (19 July 2003) A10.

Supra note 20 at 545 . 
[0]ne of the clearest instances where private international law and human rights have intersected is in the area of the recognition and enforcement of foreign judgments, a matter of great practical and commercial significance in circumstances where, whilst an individual or corporation may conduct or transact business throughout the world, that individual or corporation's assets are only located in a particular jurisdiction. ${ }^{244}$

The law in Canada on this topic has, as a preliminary matter, until just recently been governed by the judgment of La Forest J. in Morguard. ${ }^{245}$ As he stated, largely guided by principles of comity: 246 "the courts in one province should give full faith and credit, to use the language of the United States Constitution, to the judgments given by a court in another province or territory, so long as that court has properly, or appropriately, exercised jurisdiction in the action." ${ }^{247}$ The Court's approach provides for an expansive judicial ability to enforce foreign judgments in light of our modern principles of global commerce. As La Forest J. stated, it is now "imperative" that courts accommodate the flow of "wealth, skills and people" between jurisdictions. ${ }^{248}$ The Court's approach has subsequently been applied to foreign judgments as well. ${ }^{249}$ And just recently, the Supreme Court of Canada has now confirmed this approach in its decision in Beals. ${ }^{250}$ As Major J. stated, for the majority of the Court: "the 'real and substantial connection' test, which is applied to interprovincial judgments, should apply equally to the recognition of foreign judgments."251

However, notwithstanding the Morguard formulation, as applied in Beals, Canada does not enforce all foreign judgments. ${ }^{252}$ To the extent that enforcement in Canada of foreign judgments against entities with Canadian assets is refused, foreign plaintiffs may be left without any meaningful access to a remedy. As Vaughan Black has recognized, "if Canada is the only place the judgment debtor has property, then a foreign judgment we decline to enforce is useless to the judgment creditor."253

Again, we see how the issues of globalization, international human rights, and civil procedure cross paths. The decision of whether to enforce a foreign judgment, like a decision of whether to grant jurisdiction, is a meaning-producing act. It potentially means the

Bell, "Human Rights and Transnational Litigation," supra note 85 at 130.

Supra note 108.

See e.g. ibid. at 1095-101.

Ibid. at 1102. See recently Cook Nook Hazelton Lanes Ltd. v. Trudeau Corp. 1889 Inc. (2003), 125 A.C.W.S. (3d) 60 (Ont. Sup. Ct.).

See supra notes 121-22 and accompanying text.

Castel \& Walker, supra note 106 at 14.2. See also Joost Blom, "The Enforcement of Foreign Judgments: Morguard Goes Forth into the World" (1997) 28 Can. Bus. L.J. 373 at 379-84.

Supra note 112.

Ibid. at para. 19. See also ibid. at para. 28.

For a discussion of the various factors that are considered in determining whether a given judgment will be enforced, see Beals, supra note 112 at paras. 17-38; and Castel \& Walker, ibid. at 14.2-14.31. For a further discussion of common law approaches to foreign judgments, see Celia Wasserstein Fassberg, "Rule and Reason in the Common Law of Foreign Judgments" (1999) 12 Can. J.L. \& Jur. 193. See also generally H. Patrick Glenn, "Foreign Judgments, the Common Law and the Constitution: De Savoye v. Morguard Investments Ltd." (1992) 37 McGill L.J. 537: H. Scott Fairley, "Enforcement of Foreign Judgments by Canadian Courts: A New Age of Uncertainty" (1996) 2 Can. Int'I Lawyer 1; Ronald A. Brand, "Foreign Judgments in U.S. Courts" (1996) 2 Can. Int'I Lawyer 10; and Geneviève Saumier, "The Recognition of Foreign Judgments in Québec - The Mirror Crack'd" (2002) 81 Can. Bar Rev. 677 at 704-709, 713-15.

Supra note 126 at 248. 
difference between a remedy granted and a remedy denied. This is, in my view, particularly important if the judgment at issue involves damages against Canadian entities (or entities with Canadian assets) for international human rights-related violations.

While Canadian rules on jurisdiction and the enforcement of foreign judgments continue to be largely judge-made, "bit by bit, the Canadian scene is changing." 254 This change is happening more rapidly on the international stage, as contemplated, for example, by several international documents including the Brussels Convention on Jurisdiction and Enforcement of Judgments in Civil and Commercial Matters,${ }^{255}$ the Hague Convention on the Recognition and Enforcement of Foreign Judgments in Civil and Commercial Matters, ${ }^{256}$ the Lugano Convention on Jurisdiction and the Enforcement of Judgments in Civil and Commercial Matters, ${ }^{257}$ and the draft Hague Convention on International Jurisdiction and Foreign Judgments in Civil and Commercial Matters. ${ }^{258}$

While an analysis of these international regimes is beyond the scope of this project, ${ }^{259}$ it is important to note that whether enforcement determinations are based on common law, statutory ${ }^{260}$ or treaty-based principles, it will be important to take into consideration the realities of modern global commerce and the workings of MNCs if adequate protection of international human rights is to be granted by domestic courts. ${ }^{201}$

To the extent that courts are concerned with issues of "quality of justice,"262 "public policy"263 or the protection of "natural justice"264 in the context of foreign proceedings, again, the reality of modern commerce needs to be considered. For example, to the extent that MNCs take the benefit of doing business in foreign jurisdictions, they also need to be aware that their activities may be scrutinized by the courts of those jurisdictions. This is particularly so if efforts to litigate in domestic courts have failed as a result of negative preliminary jurisdictional determinations. If a court rejects a claim on forum non conveniens grounds, based partly on the notion that a foreign state has "the proven capacity to mete out fair and equal justice," ${ }^{265}$ it should take a close look at a subsequent argument that a judgment from

Ibid. at 238 .

27 September 1968, 8 I.L.M. 229 (entered into force 1 February 1973), consolidated reprint in 1998 O.J. No. C 27. See also EC, Council Regulation (EC) No. 44/2001 of 22 December 2000 on jurisdiction and the recognition and enforcement of judgments in civil and commercial matters, [2001] O.J. L. $12 / 1$.

1 February 1970 (entered into force 20 April 1979), online: Hague Conference on Private International Law <www.hcch.net/e/conventions/text16e.html>.

16 September 1988, [1988] O.J. No. L 319.

See e.g. the Hague Conference on Private International Law, "Jurisdiction Judgments," online: <www. hcch.net/e/workprog/jdgm.html>.

For a useful discussion on these initiatives, see Black, supra note 126.

See Beals, supra note 112 at para. 29, in which Major J. alludes to the future possibility of a "different statutory approach."

For a more conservative view of enforcement principles, see $i b i d$. at 266.

Morguard, supra note 108 at 1100.

See Beals, supra note 112 at paras. 71-77.

See e.g. ibid. at paras. 59-70; United States of America v. Levy, [2002] O.J. No. 2298 (Sup. Ct.), Campbell J. (QL), aff'd [2003] O.J. No. 56 (C.A.) (QL); and Society of Lloyd's v. Saunders (2001), 55 O.R. (3d) 688 (C.A.). For a useful commentary, see Geneviève Saumier, "What's in a Name? Lloyd's, International Comity and Public Policy" (2002) 37 Can. Bus. L.J. 388.

Union Carbide, supra note 2 at 867. 
that foreign jurisdiction should not be enforced locally. Again, we see the potential importance of procedural determinations - this time after a case has been tried and a judgment has been rendered - when protecting international human rights claims resulting from the negative impacts of commercial globalization. And this will become more important if class actions ${ }^{266}$ are increasingly used for the protection of international human rights.

\section{EXTRATERRITORIAL DISCOVERY}

A final procedural tool that will become of growing importance for the purpose of this discussion is extraterritorial discovery. Traditionally, evidentiary issues have largely been within the exclusive reach of domestic tribunals. As Elias has commented, "trial evidence is characteristically a matter for the procedural law of the forum." ${ }^{.67}$ However, while practical hurdles may arise ${ }^{268}$ what kinds of evidence, and from what witnesses such evidence is or is not available, will clearly have important impacts on multijurisdictional determinations. This is also an area where international treaty-based rules will increasingly apply. ${ }^{269}$

Fasken Martineau DuMoulin LLP, one of Canada's largest law firms, has recently reported that a "by-product" of the growing amount of commerce between Canadians and Americans is an increase in litigation "on both sides of the border involving the need for witnesses on the other side of the border."270 This increase in litigation is going to require more cooperation between various judicial systems - a point that has been recognized by the U.S. Court of Appeals for the Third Circuit:

Until recently, the United States has not engaged itself fully in efforts to improve practices of international cooperation in litigation. The steadily growing involvement of the United States in international intercourse and the resulting increase in litigation with international aspects have demonstrated the necessity for statutory improvements and other devices to facilitate the conduct of such litigation ... thereby providing equitable and efficacious procedures for the benefit of tribunals and litigants involved in litigation with international aspects. $^{271}$

266, See discussion supra Part IV.C.1. See also Faulk, supra note 237 at 331

267 Olusoji Elias, Judicial Remedies in the Conflict of Laws (Oxford and Portland, Oregon: Hart Publishing, 2001) at 11 .

26. For example, in Canada, the "deemed undertaking" rule - an "automatic confidentiality imposed upon evidence obtained by discovery" - may impact the right to use such evidence elsewhere, or in further litigation. See e.g. Ontario's Rules of Civil Procedure, R.R.O. 1990, reg. 194, r. 30.1(3). Similar rules, however, do not automatically apply elsewhere; for example, in the United States (see Wilson, supra note 229 at para. 19).

26.) See e.g. the Hague Convention on the Taking of Evidence Abroad in Civil or Commercial Matters, 18 March 1970, online: Hague Conference on Private International Law <www.hcch.net/e/ conventions/text20e.html>.

270) Monahan, supra note 114 at 1.

271 In re Application Pursuant to 28 U.S.C. 1782 for an Order Permitting Bayer AG, $146 \mathrm{~F} .3 \mathrm{~d} 188$ ( $3 \mathrm{~d}$ Cir. 1998 ) at para. 25, per curiam [Bayer]. For statutory material and further discussions concerning the issue of allowing parties in foreign litigation access to discovery in the United States, see e.g. 28 U.S.C. $\$ 1782(a) ;$ South Carolina Ins. Co. v. Assurantie Maatschappij “De Zeven Provincien" N.V., [1986] 1 A.C. 24 (H.L.), cited in Bayer, ibid. at para. 43; and H. Smit, "American Assistance to Litigation in Foreign and International Tribunals: Section 1782 of Title 28 of the U.S.C. Revisited" (1998) 25 Syracuse J. Int'l L. \& Com. 1, cited in ibid. at para. 49. 
The Canadian judiciary has also commented on this phenomenon. As Cumming J. recently stated, the issue of "gathering relevant evidence through discovered evidence in extraterritorial jurisdictions ... will have increasing importance given the inexorable increase in the marketing of the same products globally by multinational enterprises though trade in integrated markets."272

It was this issue that was largely before Cumming J. in the VitaPharm case. ${ }^{273}$ That case was dealt with in the context of parallel price-fixing proceedings in various Canadian provinces and in a consolidated proceeding in the United States District Court for the District of Columbia. The Court was asked to prevent the plaintiffs in the Ontario proceeding from gaining access to discovery evidence gathered in the United States litigation. In refusing the relief sought, Cumming J. stated that, in the context of American and Canadian business activity: "If both societies are to maximize the benefits of expanding freer trade and open markets, the legal systems of both countries must recognize and facilitate an expeditious, fair and efficient regime for the resolution of litigation that arises from disputes in either one or both countries."274

The issue of discovery and trial evidence can also arise as a factor to be considered in the context of forum non conveniens determinations. ${ }^{275}$ To the extent that a "legitimate" juridical advantage includes the right to access certain witnesses or types or locations of evidence, those advantages "will be available" in so much as they will be weighed in the balance along with all other "relevant factors."

If these evidentiary determinations are involved in cases that, in substance, deal with international human rights violations resulting from the negative impacts of commercial globalization, then again we see the important coming together of globalization and international human rights on the one hand, and civil procedure on the other. And the stronger the roots of international commerce grow, the more likely we are to see a repeat of the kinds of human rights violations that were at issue, or that could have been at issue, in the UCC or Cambior contexts. Facilitating evidentiary determinations in these contexts will, therefore, be critical in the ultimate project of fostering the meaningful protection of international human rights through domestic civil processes. (Gen. Div.), leave to appeal to C.A. refused (1994), 18 O.R. (3d) 26, leave to appeal to S.C.C. refused (1994), 19 O.R. (3d) i. See also Incorporated Broadcasters, supra note 132; MacDonald v. Lasnier (1994), 21 O.R. (3d) 177 (Gen. Div.); SDI Simulation Group Inc. v. Chameleon Technologies Inc. (1994), 34 C.P.C. (3d) 346 (Ont. Gen. Div.); and ABB Power Generation Inc. v. CSX Transportation (1996), 47 C.P.C. (3d) 387 (Ont. Gen. Div.). 


\section{CONClusion}

The Supreme Court of Canada has repeatedly claimed that order and fairness govern jurisdictional and related procedural determinations. ${ }^{277}$ Between these, however, as La Forest J. has stated, "order comes first. Order is a precondition to justice." ${ }^{278}$ While order - in its many procedural manifestations - may well be a precondition to justice, it is critical, as discussed in this article, that modern manifestations of globalization and their impacts on fundamental international human rights and interests are also taken into account when determining principles of order. Again, as Sopinka J. stated in Amchem, "parochial" judicial attitudes are "no longer appropriate."279

This recognition is of growing importance in this era of commercial globalization in which mass tort litigation ${ }^{280}$ and litigation involving the internet ${ }^{281}$ are becoming more prevalent and increasingly international. The increased prevalence of arbitration clauses, ${ }^{282}$ and choice of law and choice of forum clauses in commercial contracts, ${ }^{283}$ often signed in the context of uneven bargaining power, coupled with the rise of statutory and treaty-based jurisdictional tools, will mean that courts may be faced with difficult choices. This is especially so when such clauses, statutes or treaties result, in a given case, in a potential denial of justice or respect for international human rights. ${ }^{284}$ Further, with advances in technology facilitating innovations in approaches to global business, jurisdictional pressures on our courts will

Morguard, supra note 108 at 1097; Tolofson, supra note 132 at 1058; and Beals, supra note 112 at paras. 21-22.

278 Tolofson, supra note 132 at 1058. See also Hunt, supra note 132 at 326 , cited in Recherches Internationales, supra note 116 at para. 40: "Whatever approach is used, the assumption of and the discretion not to exercise jurisdiction must ultimately be guided by the requirements of order and fairness, not a mechanical counting of contacts or connections."

279. Amchem, supra note 1 at 334.

280 As Janet Walker has argued, "mass torts ... are increasingly multi-jurisdictional in nature" (supra note 113 at 108).

281 As Geneviève Saumier has commented: "Everyone readily admits that the era of Internet transactions poses new challenges to private international law, in terms of jurisdiction, recognition and choice-oflaw." G. Saumier, "Morguard and the Plaintiff's Choice of Forum" in Looking Ahead, supra note 113 at 134 [citation omitted]. See also Panel Discussion, "Is the Internet Subverting National Borders?" in Looking Ahead, supra note 113 at 283, 297-303, cited in ibid.; and Elizabeth G. Thornburg, "Privatisation and Power: Dispute Resolution for the Internet" in Rickett \& Telfer, supra note 237 at 303-29. For discussion and statistics regarding the use of the internet and internet commerce in Canada, see e.g. Canada, Department of Justice, Research \& Statistics Division, Questions \& Answers: Electronic Commerce (Ottawa: Government of Canada, 2002), online: Department of Justice <www. canada.justice.gc.ca/en/ps/rs/rep/qa02-1-e.pdf $>$.

282 See e.g. Katherine Lynch, The Forces of Economic Globalization: Challenges to the Regime of International Commercial Arbitration (The Hague: Kluwer Law International, 2003).

28.3 See e.g. M. Paul Michell, "Forum Selection Clauses and Fundamental Breach: Z.I. Pompey Industrie v. Ecu-Line N.V., The Canmar Fortune" (2002) 36 Can. Bus. L.J. 453; G. Born, "Forum Selection Clauses Anatomized" (May 1999) Int'l Comm. Lit. 26; and M.J. Coffino \& M.T. Wolff, "Choice of Law and Forum Clauses" (Dec. 1995 - Jan. 1996) Int'I Comm. Lit. 37.

284 For judicial discussion of waiving jurisdiction clauses in the context of potential human rights and other considerations, see e.g. McDonnell Douglas Corporation v. Islamic Republic of Iran, $758 \mathrm{~F} .2 \mathrm{~d} 341$ (8th Cir. 1985), cert. den'd 474 U.S. 948 (1985); Rasoulzadeh v. Associated Press, 574 F.Supp. 854 (S.D.N.Y. 1983), aff'd 767 F.2d 908 (2d Cir. 1985); Oppenheimer v. Cattermole, [1976] A.C. 249; The Eleftheria, [1970] P. 94; and Ellinger v. Guiness Mahon \& Co., [1939] 4 All. E.R. 16, cited in Bell, "Human Rights and Transnational Litigation," supra note 85 at 124-25. 
become even greater ${ }^{285}$ Finally, we are also, not surprisingly, starting to see the globalization of business breakdown in the form of international insolvency matters. ${ }^{286}$ This trend will also challenge our traditional procedural approaches and tools.

The two purposes of this article - to highlight the vital role for domestic legal communities in the post-World War II international human rights project, and more generally, to help bring alive the power and increasingly-global context of civil procedure - demonstrate the important convergence of globalization and international human rights on the one hand, and civil procedure on the other. While travelling through Bhopal may help to bring alive this convergence, its significant legal relevance will increasingly start in domestic courts right here at home. command the sky, anything that can be sent on a data link can be sourced almost anywhere ... U.S. and Canadian IT service firms are busy setting up operations in India and other offshore spots..." (J. Saunders "IT Jobs Contracted From Far and Wide" The Globe and Mail (14 October 2003) B1 at B4). 